\title{
Moving up or falling behind? Gender, promotions, and wages in Canada*
}

\author{
Mohsen Javdani \\ Department of Economics \\ University of British Columbia-Okanagan \\ Andrew McGee \\ Department of Economics \\ Simon Fraser University
}

May 2015

\begin{abstract}
We estimate gender differences in promotion experiences for a representative sample of Canadian workers using linked employer-employee data. We find that women in Canada are 3 percentage points less likely to be promoted and have received fewer promotions than similar men, but these differences stem almost entirely from gender differences in industry and occupation. By contrast, women experience an estimated 2.9 percent less wage growth in the year of a promotion than similar men even after controlling for industry, occupation, and firm effects - though a significant "family gap" exists among women as single women and women without children experience essentially the same wage returns to promotion as men.
\end{abstract}

JEL codes: J16, J31, J62, J71.

Keywords: Promotions, gender wage gap

*Javdani: mohsen.javdani@ubc.ca, 3333 University Way, Kelowna, BC V1Y 9M5, Canada. McGee: amcgee@sfu.ca, 8888 University Drive, Burnaby, BC V5A 1S6, Canada. 


\section{Introduction}

The difficulties women face in advancing to the highest levels of corporate leadership have been the subject of much discussion among both academics and business leaders (Bertrand and Hallock 2001, Matsa and Miller 2011, Smith et al. 2013, Sandberg 2013). Surprisingly little consensus, however, exists concerning gender differences in promotion experiences more generally. Some studies find that women are less likely to have been promoted than men (e.g., Olson and Becker 1983, McCue 1996, Winter-Ebmer and Zweimuller 1997, Cobb-Clark 2001, Ransom and Oaxaca 2005, Blau and DeVaro 2007, Johnston and Lee 2012), others the opposite (e.g., Gerhart and Milkovich 1989, Hersch and Viscusi 1996), while still others find no gender difference in promotion probabilities (e.g., Lewis 1986, Booth et al. 2003). Similarly, some studies find that women experience smaller wage returns to promotion than men (Hersch and Viscusi 1996, Booth et al. 2003, Johnston and Lee 2012), others the opposite (Cobb-Clark 2001), while still others find that women experience comparable wage gains (Olson and Becker 1983, Blau and DeVaro 2007, Cassidy et al. 2012).

In this study, we provide the first estimates of gender differences in promotion experiences for a nationally representative sample of Canadian workers. ${ }^{1}$ Using linked employer-employee data from the Workplace and Employee Survey (WES) from 2000 to 2004 allows us to account for firm-level differences that may be important if women tend to be employed in firms with flatter job ladders or offering lower wage returns to promotions in light of growing evidence of systematic inter-firm gender segregation in the labour market (e.g., Groshen 1991; Reilly and Wirjanto 1999; Carrington and Troske 1995; Bayard et al. 2003; Javdani 2015). We find that

\footnotetext{
${ }^{1}$ Yap and Konrad (2009) estimate gender differences in promotion experiences for Canadian workers from a single, national firm in the IT sector.
} 
women are an estimated 3 percentage points less likely to have been promoted and have received 0.24 fewer promotions than similar men, but these gaps stem almost entirely from gender differences in the industries and occupations of employment. By contrast, women experience an estimated 2.9 percent less wage growth in the year of a promotion than similar men even after controlling for industry, occupation, and firm effects.

Examining differences among women in promotion experiences, we find striking evidence of a "family gap" (Waldfogel 1998). Recent evidence from Norway suggests that women with families are less likely than other women to move up the career ladder (Kunze 2014). While we find no evidence that women with families are less likely to be promoted than similar women without families in Canada, we do find a "family gap" in women's wage returns to promotions: women with children and married women experience significantly less wage growth following promotions than childless and single women, who experience wage returns to promotion similar to those of men. Notably, the wage returns to promotion are lowest among women with families in the top quartile of the wage distribution, which suggests a possible mechanism through which the well-documented "glass ceiling" in earnings faced by women could emerge (e.g., Albrecht et al. 2003, Arulampalam et al. 2007, Javdani 2015).

The "family gap" in women's wage returns to promotions might arise if firms discriminate against promoted women with families, if women with families pursue or are offered "smaller" promotions, or if women with families invest less in human capital on-the-job and are less productive once promoted as a consequence. While we cannot rule out discrimination, we find no evidence that women experience smaller wage returns to promotion because they receive "smaller" promotions that entail smaller increases in hours and supervisory responsibility than similar men. Likewise, we find no evidence that the smaller wage returns to promotion 
experienced by women can be explained by women's participation in on-the-job training (OJT) or other career training.

Women's wage growth following promotions may suffer if firms are not required to compete as hard to retain their services following promotions as they would for comparable men as in the "sticky floors" model (Booth et al. 2003). This might occur if women with families have less time to devote to job search or are less mobile due to family concerns. To indirectly examine this possibility, we explored transition patterns between interviews for workers in the WES and found that women were significantly more likely than men to remain with the same employer between interviews. Though not conclusive, women in the WES do appear to have been less mobile or to have had worse outside options than their male peers, which would be sufficient to generate the lower wage returns to promotions for women that we observe. That said, we found no difference in transition patterns between women with and without families conditional on their observed characteristics, indicating that the family gap in women's promotion experiences requires a more nuanced explanation than differences in mobility.

The lack of consensus concerning gender differences in promotions in the existing literature is likely due in part to the use of non-representative samples from a single firm (e.g., Gerhart and Milkovich 1989, Hersch and Viscusi 1996, Ransom and Oaxaca 2005, Yap and Konrad 2009), a specific industry (e.g., Lewis 1986, Spurr 1990), or a specific groups or cohorts of workers (e.g., Cobb-Clark 2001, Blau and DeVaro 2007, Addison et al. 2014). Among the studies using representative samples of workers, our findings are most similar to those of Booth et al. (2003), who find that controlling for industry and occupation British women were no less likely to have been promoted but experience smaller wage returns to promotion. Johnston and Lee (2010) also find that university-educated Australian women under 40 experienced smaller wage returns to 
promotions than similar men, but they also find that these women are less likely to be promoted than similar men even after controlling for industry and occupation.

Differences between our findings and those of other studies may also reflect heterogeneity in gender differences in promotion experiences other than the "family gap" discussed above. To this end, we examined gender differences in promotion experiences within well-defined subpopulations. We find that the gender differences in the wage returns to promotions are most pronounced among workers with less than a bachelor's degree and workers in occupations which are not predominantly female. We find no statistically significant gender differences in the probability of promotion in any subpopulation after controlling for industry and occupation.

Overall our findings highlight the key role played by domestic constraints in limiting women's wage returns to promotion and suggest the need for social policies addressing gender disparities in internal labor markets. The fact that both the highest and lowest income women with families see the smallest wage returns relative to similar men indicates that the difficulties working women with families face affect Canadians broadly.

\section{Data}

The WES was a longitudinal survey of approximately 6,000 Canadian employers and their employees between 1999 and 2006. ${ }^{2}$ The target population of employers consisted of all business locations in Canada with paid employees in March of the survey year. ${ }^{3}$ In the 1999, 2001, 2003,

\footnotetext{
${ }^{2}$ In 2006 only the employer part of the survey was administered.

${ }^{3}$ Employers in the Yukon, Nunavut and Northwest Territories and employers operating in crop production, animal production, fishing, hunting, trapping, private households, religious organizations and public administration were excluded from the sample. Public administration, which includes establishments primarily engaged in the enactment and judicial interpretation of laws and their pursuant regulations and the administration of programs based on them, accounts for around 6.5 percent of employment in Canada (Statistics Canada, Table 281-0024).
} 
and 2005 surveys, the sample of employers was refreshed with new employers from the Statistics Canada Business Register to maintain a representative cross-section of Canadian firms. A maximum of twenty-four employees were interviewed from each sampled firm in each odd year and re-interviewed the following year. ${ }^{4}$ When properly weighted, the employee sample is representative of the Canadian workforce in the target population of employers; all of our analysis incorporates sample weights from Statistics Canada. Our main analysis is based on the pooled 2000, 2002, and 2004 cross-sections of employees who had been interviewed the year prior and had not changed employers in the interim. We restrict the sample to workers between the ages of 19 and 65 who worked more than 30 hours per week from firms that have at least two sampled workers. These restrictions result in a sample of 16,654 women and 24,192 men from 5,840 firms.

The dependent variables in our study are an indicator for whether the worker was promoted between interviews, the number of times the worker had been promoted with the current employer, and the change in the worker's log-hourly wage between interviews. Changes in pay and responsibilities are generally thought to be the distinguishing features of promotions (Pergamit and Veum 1999), and our data identify promotions using precisely these two features. Specifically, workers were asked, "Have you ever been promoted while working for this employer? (By promotion we mean a change in duties/responsibilities that led to both an increase in pay and the complexity or responsibility of the job.)" Studies identifying promotions using changes in job titles or hierarchical levels (e.g., Booth et al. 2003, Cassidy et al. 2012, Kunze 2014) may inadvertently classify "lateral" moves in which job titles change as promotions or miss promotions within job titles or broadly defined hierarchical levels. If the date of the most

\footnotetext{
${ }^{4}$ The number of workers interviewed from each firm was proportional to firm's size except for workplaces with fewer than four employees in which all employees were surveyed.
} 
recent promotion is after the date of the first interview, then the "promoted" indicator is set to 1 and 0 otherwise. If workers indicated that they had been promoted, they were asked the number of times they had been promoted by their current employer.

In addition to employing firm fixed effects, we control for worker characteristics, industry of employment (14 categories), and broad occupational categories (6 categories). Among the worker characteristics are race and immigrant status (white Canadian, visible minority Canadian, white immigrant, visible minority immigrant), gender, language spoken at home (3 categories), highest level of schooling (8 categories), marital status (6 categories), number of dependent children ( 5 categories), age (9 categories), years of (actual) full-time labour market experience and its square, and whether the respondent's job is part of a collective bargaining agreement (CBA) or union.

Table 1 provides summary statistics for men and women in our sample as a whole and by promotion status. Unconditionally, women in our sample fare worse than men where promotions are concerned. Only 24 percent of the women were promoted between interviews compared to 27 percent of the men, and women had received nearly 0.3 fewer promotions with their employers. Likewise, promoted women experienced wage growth on average of only $4.1 \log$ points between interviews relative to $6.5 \log$ points for promoted men.

Women in our sample tended to have less experience, were less likely to have children, and were less likely to be high school dropouts than men - all characteristics related to the promotion outcomes we examine. Perhaps more importantly, our sample exhibits significant gender segregation by industry with 32 percent of women employed in the education and health care industries compared to only 11 percent of men, who were more likely than women to work in the 
manufacturing, construction, and transportation industries. Similar gender segregation in occupations is also apparent: 52 percent of men worked in a technical trade relative to only 33 percent of women, while 23 percent of women worked in clerical and administrative positions relative to only 6 percent of men. This gender segregation contributes to differences in promotion experiences if women work in positions with flatter job ladders, and this appears to be the case. For example, only 16 percent of workers in the education and health care industries were promoted between interviews compared to 27 percent of workers in all other industries. Given the overrepresentation of women in this industry, gender segregation along these lines alone is likely to give rise to significant differences in promotion experiences. In the next section, we consider whether differences in worker characteristics, industries, occupations, and firms explain the gender differences in promotion experiences.

\section{Findings}

\section{III.A Probability and number of promotions}

Following Olson and Becker (1983), we assume a worker is promoted when he/she is expected to be more productive in the new position than his/her peers while meeting some minimum productivity standard for the firm. We operationalize the model by estimating linear probability models of promotion $\left(\right.$ Promote $_{i k}=0$ or Promote $\left._{i k}=1\right)$ of the form:

$$
\text { Promote }_{i k}=X_{i} \beta+\text { SFemale }_{i}+\mu_{k}+\varepsilon_{i k}
$$

where $X_{i}$ are the observed productivity correlates of worker $i ; \mu_{k}$ is a firm effect capturing interfirm differences in promotion rates conditional on workers' characteristics; and $\varepsilon_{i k}$ includes the unobserved productivity correlates of worker $i$ as well as worker-firm unobservables such as the quality of the worker's next best peer. 
The conditional gender difference in the probability of promotion, $\delta$, consists of the aggregated effects on the probability of promotion of unobserved differences between men and women and any statistical or taste-based discrimination on the part of firms. When the firm effects, $\mu_{k}$, are excluded from equation (1), $\delta$ measures the conditional economy-wide gender differences in promotion, while it measures the conditional within-firm gender difference when firm effects are included. As such, the inclusion of firm effects allows us to distinguish between intra-firm barriers to advancement and gender segregation in hiring that may lead women to find employment in firms using flatter job ladders. ${ }^{7}$

Panel A of table 2 reports the estimated gender difference in the probability of promotion for specifications of (1) with different controls; appendix table 1 provides the coefficient estimates for the remaining controls in our preferred specifications. Unconditionally, women in our sample are 2.8 percentage points less likely to have been promoted in the last year than men. Controlling for worker characteristics in column 2 , women are 3.1 percentage points less likely to have been promoted than men.

Columns 3, 4 and 5 add controls for the worker's industry, occupation, and both industry and occupation, respectively, to the controls in column 2 to account for the possibility that women may be employed in industries or occupations with shorter job ladders and fewer opportunities for promotion. Controlling for the industry (occupation) in which a worker is employed, the estimated gender gap falls to 1.9 (2.2) percentage points. Controlling for both industry and occupation, women are 0.7 percentage points less likely to have been promoted than their male peers - a difference which is not statistically significant. Column 6 adds firm effects to the model

\footnotetext{
${ }^{7}$ DeVaro and Brookshire (2007), for example, show that promotions are less common in nonprofit firms in which women are disproportionately employed.
} 
in column 5, but the estimated gender gap in promotion probabilities $(-0.008)$ is little changed. Collectively, the estimates in panel A suggest that the gender difference in the probability of promotion is driven by gender segregation in occupation and industry rather than systematic sorting into firms offering fewer opportunities for advancement.

For the sake of comparison among studies employing similar controls and using representative samples, Cobb-Clark (2001) finds that women in the United States in the NLSY79 in their twenties and early thirties were 3.8 percentage points less likely to have been promoted than their male peers. Addison et al. (2015) join Cobb-Clark (2001) in finding that young women in the NLSY79 are less likely to have been promoted than their male peers, but they find that this gap reverses itself at later stages in their careers. Like these studies, we find some evidence (though not statistically significant) that young women fare worse in terms of the probability of promotion than older women. Johnston and Lee (2012) find that young, university-educated women (but not less educated women) in Australia were 3.7 percentage points less likely to have been promoted than their male peers. By contrast, we find that university-educated women in Canada are at least as likely as men to have been promoted, and that, if anything, less educated women are the ones who fare worse in terms of the probability of promotion. We discuss our findings with respect to age and education in section III.D. Finally, Booth et al. (2003) find that women in the United Kingdom are slightly more likely to have been promoted than men. While we join Booth et al. in finding limited evidence of a gender gap in promotion probabilities, we note that in their sample women were in fact more likely to have been promoted than men unconditionally. Further, their controls for industry and occupation have no effect on their estimates, which suggests either that industry and occupation gender segregation have very 
different effects on women's promotion experiences in Canada than in the United Kingdom or that the gender segregation patterns in the two countries are very different.

The existing studies of gender differences in promotion experience focus exclusively on gender differences in the probability of promotion, but differences in the probability of promotion may understate differences in the promotion experiences of men and women if the two groups are promoted with different frequency. We take up this issue in panel B of table 2 by estimating OLS models similar to that in (1) using the number of promotions received with the current employer as the dependent variable. ${ }^{8}$ Unconditionally, women in our sample received 0.293 fewer promotions with their employer than their male peers. Controlling for worker characteristics in column 2, women received an estimated 0.244 fewer promotions than similar men. Controlling for industry (occupation), the gap falls to $0.161(0.176)$ fewer promotions. Controlling for both industry and occupation with or without firm fixed effects, the gender difference in the number of promotions received is small $(-0.089$ or -0.074$)$ relative to the mean number of promotions received in our sample (1.40 and 1.11 for men and women, respectively). Overall, our findings point to non-trivial gender differences in the probability and number of promotions that stem almost entirely from gender differences in industry and occupation.

\section{III.B Wage returns to promotions}

We estimate the log-wage growth model:

$$
\Delta w_{i, k}=\alpha_{0} N P F_{i}+\alpha_{1} P_{i}+\alpha_{2} P F_{i}+X_{i} \Theta+\mu_{k}+e_{i}
$$

${ }^{8}$ We estimate the probability and number of promotions models using OLS for the ease of incorporating firm effects, but probit and Poisson estimators result in estimated marginal effects for the probability and number of promotion models, respectively, similar to those in the tables. 
where $\Delta w_{i, k}$ is the change in log-wages between interviews for worker $i$ at firm $k ; N P F_{i}$ is an indicator for being a non-promoted female; $P_{i}$ is an indicator for whether worker $i$ was promoted between interviews; $P F_{i}$ is an indicator for being a promoted female; $\mu_{k}$ is a firm effect; and $e_{i}$ is the error term. The wage growth associated with promotions not explained by observed characteristics $\left(X_{i}\right)$ is given by $\alpha_{1}$ for men and $\alpha_{1}+\alpha_{2}$ for women. This wage growth may reflect the fact that promoted workers are more productive in their new positions, but it may also capture compensating differentials paid to promoted workers for increases in responsibilities and hours as well as premiums paid to promoted workers as part of incentive mechanisms built into compensation schemes.

Panel $\mathrm{C}$ of table 2 reports estimates of the gender difference in the wage returns to promotion for different specifications of the model in (2). ${ }^{9}$ Unconditionally, women experienced an estimated 2.4 percent less wage growth in years in which they were promoted than promoted men. Controlling for worker characteristics, industry and occupation in columns 2 through 5 has little effect on this estimated gender gap in the returns to promotion: promoted women experienced an estimated 2.8 percent less wage growth between interviews than similar promoted men-whose wages increased by 2.5 percent-even with all of these controls in column 5 .

Prior studies have documented that women in Canada and the United States sort into "low wage" firms (e.g., Bayard et al. 2003, Javdani 2015). We add firm fixed effects in column 6 to investigate whether women sort into firms offering smaller unexplained wage returns to

${ }^{9}$ A number of different specifications have been used in the literature to estimate the relationship between promotions and the change in log-wages. In addition to the models presented in table 2 , we also estimated models including changes in worker characteristics among the controls as in Cobb-Clark (2001) and allowing the returns to worker characteristics to depend on whether one was promoted given that the marginal productivities of skills may be different in the new position. In each of these specifications, however, the estimated gender differences in the wage returns to promotion unexplained by the controls were similar to those reported in table 2 . 
promotions - perhaps firms that pay smaller compensating differentials for the presumably harder work, longer hours, and greater responsibility that come with promotions. The inclusion of firm effects, however, explains none of the observed difference in the returns to promotion: promoted women experienced an estimated 2.9 percent less wage growth than similar promoted men in the same firm.

The lower returns to promotions experienced by women may result from women pursuing promotions to less demanding positions or firms electing to promote women to less demanding positions in anticipation of lower productivity given the effort women exert in non-market activities (Becker 1985). Investigating whether women earn less than men after promotions because they are less productive would require firm-level data sets with measures of worker productivity as in Blau and DeVaro (2007). Our data do not include such measures, but they do allow us to investigate whether women pursue promotion to less demanding jobs. Workers were asked their usual hours per week, weeks worked per year, the number of employees that they supervise, and the number of unpaid overtime hours per week required of them in their current job. We take these job characteristics as proxies for the difficulty of the job and assume that "larger" promotions are associated with larger increases in time spent working and/or supervisory responsibility.

The summary statistics in table 1 indicate that in our sample, promoted and non-promoted men work longer hours every week, supervise more workers, and work more hours of unpaid overtime each week than their female peers. Following promotions, however, women see larger (though not statistically significant) increases in hours per week, the number employees supervised, and hours per week of unpaid overtime than their promoted male peers. In column 7 of table 2, we add controls for hours and responsibilities and the changes in these variables 
between interviews to the model in column 6 , but estimated gender differences in the wage returns to promotion $(-0.027)$ is little changed-suggesting that neither the hours and responsibilities required on a job nor the changes in hours and responsibilities resulting from a promotion explain the wage growth penalty experienced by promoted women.

Another possibility is that women might invest less mid-career in human capital and thus be less productive upon promotion. Table 1 also reports summary statistics for whether a worker participates in on-the-job training (OJT) between interviews, the number of days spent in OJT between interviews, whether the worker opted to not participate in OJT when such training was available through the employer, and whether the worker received career-related training not through the employer between interviews. We find no evidence that promoted women were less likely to participate in training than promoted men. While promoted men spent more time in OJT, more promoted women participate in such training. Column 8 of table 2 adds these controls

for participation in training to the specification in column 6 . The wage growth penalty faced by promoted women remains 2.9 percent, which suggests that promoted women do not experience slower wage growth than their male peers because of differences in (measured) mid-career human capital acquisition.

\section{III.C The "family gap" in promotion experiences}

A number of studies suggest an important role for families and fertility decisions in gender differences in wages in Canada more generally (Phipps et al. 2001) and in promotion outcomes specifically (e.g., Kunze 2014, Addison et al. 2015). In table 3, we consider whether the promotion experiences of married women and women with children are distinctly different from those of single women and women without children, respectively. Panel A of table 3 reports 
estimates of the gender differences in the probability, number and wage returns to promotion models in table 2 in which we replace the indicator for being female with indicators for being a single female and for being a married female, while panel B replaces the female indicator with indicators for being a woman with children and for being a childless woman. For all women regardless of marital status or the presence of children, controlling for industry and occupation explains a large fraction of the gender differences in the probability and number of promotionsalthough married women and women with children have still received an estimated 0.10 fewer promotions than similar men even after controlling for occupation and firm effects in column 6. Women do indeed appear to end up in positions with fewer opportunities for advancementperhaps in exchange for the more flexible work schedules offered in nursing, teaching and administrative work or perhaps due to limited access to other careers due to discrimination as in the "crowding" hypothesis (Sorensen 1990) — but this sorting does not appear to be driven entirely by family considerations.

A family gap in women's promotion experiences, however, is starkly evident when we consider the wage returns to promotion. Single women and women without children who are promoted experience the same or - in the case of single women — possibly even higher wage returns to promotion than similar men controlling for occupation and firm effects in column 6. Married women and women with children who are promoted, however, experience an estimated 4.2 and 5.9 percent, respectively, less wage growth than similar promoted men between interviews. The gender difference in the wage returns to promotion reported in table 2 is driven entirely by women with families whose wages fall behind their male peers even when they ascend the corporate ladder. 
The family gap in the wage returns to promotion may result from women with families taking on a greater share of domestic production, leaving them less productive in the workplace. One might expect, however, that higher income families are able to substitute purchased inputs such as nannies and prepared meals for the woman's time and that the family gap might be smaller as a result among high income women. We examine this issue in table 4, which reports estimates of the gender difference in the wage returns to promotion by quartile of the overall income distribution (i.e., including both men and women) based on wages reported in the first year the worker was interviewed. We interact all covariates with indicators for the income quartile and again constrain the firm effects to be the same for all workers. Before considering how the family gap depends on income quartile, panel A reports the estimated wage returns to promotion by income quartile for women as a whole relative to similar men. While women in all quartiles of the income distribution experience smaller wage growth following a promotion than similar men in the same income quartile, the gender difference in wage returns as a percent of wage growth is largest for women in the top and bottom quartiles of the income distribution. Promoted women in the lowest (highest) quartile experience an estimated 8.1 (6.8) percent less wage growth between interviews than similar promoted men in the same firm and in the same occupation.

The bottom two panels of table 6 allow wage growth following a promotion to depend on the worker's income quartile and whether the worker is single or childless. All promoted women in the bottom half of the income distribution experience less wage growth following promotions than their male peers regardless of whether they have families. By contrast, single women and women without children in the top half of the income distribution experience wage growth following promotions comparable to their male peers, while married women and women with 
children in the top half of the income distribution experience significantly less wage growth following promotions than their male peers. Promoted women with children in the top quartile of the income distribution, for instance, experience 15.7 percent less wage growth following a promotion than similar men. Far from being able to compensate for domestic constraints with income, high income women - perhaps by virtue of the nature of the jobs associated with being high income - are even less able to keep pace with their promoted male peers than other women, which is likely one mechanism through which the "glass ceiling" in earnings faced by women emerges.

One explanation for the lower wage returns to promotions experienced by women with families is that firms are able to pay promoted women with families less than promoted men because these women have worse outside options as in the "sticky floors" model (Booth et al. 2003). Women with families might have less time to devote to networking and job search or their job mobility may be limited by a spouse's career or other family concerns. While we are unable to directly observe women's outside options, we are able to observe transitions for all workers in the WES employee sample in odd years regardless of whether they are in our final sample, which is restricted to workers employed with the same employer as in the first interview. In even years, respondents either remain with the odd-year employer, have moved to a new employer, have no employer, or are not interviewed. In the absence of search frictions, women should be just as mobile as similar men and thus have comparable outside options. The means in the top panel of table 5, however, suggest that this is not the case. More women in the WES (72.3 percent) than men (70.3 percent) remain with their employers between interviews. Men are more likely to report being with a new employer in the second interview and more likely to not be interviewed in the even year. We suspect that most of the non-interviews are workers who have left the 
original employer given that the WES would have had a relatively easy time locating workers who remained with their initial employers given that the employers themselves were also being surveyed. As such, we take the higher proportion of women remaining with their original employers and the higher proportions of men not interviewed or with new employers as prima facie evidence that women in the WES were less mobile than men.

There are also some signs of a family gap in mobility patterns. Married women (women with children) were 8 (4.5) percentage points more likely to still be with their original employers in the even-year interview than single women (women without children) while also being 6.1 (3.4) percentage points less likely to not be interviewed in the even year. Similar patterns exist for men — suggesting that workers without families were substantially more mobile than those with families.

These summary statistics, however, do not account for gender differences in worker characteristics. The bottom panel of table 5 reports average marginal effects on the probability of different transition outcomes from a multinomial logit model controlling for worker characteristics, occupations, and firm effects. Women were an estimated 3.5 percentage points more likely than men to remain with their employers between interviews-largely because they are 3.1 percentage points less likely to not be interviewed. The evidence of a family gap in transition outcomes, however, is not so clear in the multinomial logit estimates. Single women and women without children were actually more likely than married women and women with children to remain their current employers and less likely to transition to new employers. On the other hand, married women and women with children were more likely to transition to unemployment than similar single women and women without children and less likely to transition to being non-interviewed. On the whole, our estimates suggest that women in the WES 
were indeed less mobile than men, but we do not find clear evidence of differences in mobility among women to explain the family gap in women's promotion experiences.

\section{III.D Gender differences by age, education, tenure, and predominantly female jobs}

In this section, we investigate gender differences in promotion experiences in different subsamples that might underlie some of the disparate results in the earlier literature. We make use of the fact that our sample is an order of magnitude larger than many samples used in the literature to explore heterogeneity in promotion experiences by whether a worker is employed in a predominantly female occupation, tenure, age, and education.

Table 6 reports estimates from our preferred specifications of the probability of promotion, number of promotions, and log-wage growth regressions controlling for worker characteristics, occupations, and firm effects (column 6 of table 2) for a series of paired, mutually exclusive and collectively exhaustive subsamples. Each model is estimated for both subsamples simultaneously with interactions between the controls and an indicator for whether the worker belongs to one of the subsamples so that the firm effects are constrained to be the same for workers in both subsamples.

The first set of estimates in table 6 considers whether women who work mostly with other women experience disadvantages relative to their male peers where promotions are concerned. Paulin and Mellor (1996) found that women working in occupations with more women were less likely to be promoted than women in other occupations using data from a single firm in the financial industry. We focus instead on how women in predominantly female occupations fare relative to men in these occupations and split the sample into workers in industry-occupation pairs in which more than 80 percent of the workers in the 2001 Census of Canada were women 
and all remaining workers. Women in these predominantly female industry-occupations are slightly (though not significantly) less likely to have been promoted than their male peers, have been promoted a similar number of times, and experience similar wage growth following promotions relative to their male peers. ${ }^{11}$ The downside for these women is that promotions in predominantly female occupations are not associated with significant wage growth. ${ }^{12}$

The next set of estimates considers whether women lose ground relative to men in terms of promotions at the outset of the employment relationship. Blau and DeVaro (2007) estimate gender differences in promotion experiences using a sample of the most recently hired workers in a representative set of establishments and find that recently-hired women are 2-3 percentage points less likely to be promoted but earn approximately the same amount from promotions as their male peers. The fourth panel of table 5 estimates gender differences in promotion experiences for workers with two years or less of tenure and those with more than two years of tenure. While differences in the samples used in our studies limit the conclusions one can draw from comparisons, we find that women with less than two years of tenure are more likely (though not significantly) to have been promoted but experience 2 percent less wage growth following promotions than similar men with less than two years of tenure-returns to promotion which are imprecisely estimated due to the relatively small number of such workers in our data but similar to our estimates for the sample as a whole.

\footnotetext{
${ }^{11}$ Addison et al. (2014) find that men in the NLSY79 in traditionally female jobs are more likely than women to be promoted without controlling for worker characteristics.

${ }^{12}$ We find that the wage growth penalty for promoted women is similar in predominantly female occupations and all other occupations using any threshold for "predominantly female" less than 80 percent - suggesting that only in professions in which almost all workers are women do women experience wage returns to promotions similar to their (few) male peers.
} 
The next two sets of estimates examine whether the gender differences in promotion experiences among Canadian workers depend on the age and education of the workers, respectively. As mentioned previously, Cobb-Clark (2001) finds that women in the NLSY79 were less likely to have been promoted than similar men in their twenties and early thirties, while Addison et al. (2015) find that women in this cohort were more likely to be promoted later in their careers. Johnston and Lee (2012) find that among Australian workers with less than 20 years of experience and a bachelor's degree, women are an estimated 3.7 percentage points less likely to have been promoted and experience 5 percent less wage growth following promotions than men. They found no gender differences in promotion experiences among older workers and workers with less than a bachelor's degree. Splitting our sample into workers under and over age 40 , we find that women under 40 are an imprecisely estimated 1.5 percentage points less likely to have been promoted and have been promoted 0.18 fewer times than similar young men. Women over 40 , on the other hand, were no less likely to have been promoted and had been promoted a similar number of times with their employers relative to similar older men. Given that promotions are concentrated early in the career and the significant wage returns associated with these early promotions (McCue 1996), the differences in the promotions received early in the career may cause women's wages to fall behind their male peers never to recover as a result of this difference. Indeed, Manning and Swaffield (2008) find that the gender wage gap in the United Kingdom emerges in the first decade of the career through a gender difference in wage growth. Both younger and older promoted women in our sample, however, experience 2.9 percent less wage growth relative to similar promoted men between interviews.

The final set of estimates examines how gender differences in promotion experiences depend on education. In contrast to Johnston and Lee (2010) who focus on university-educated workers 
because they observe no gender differences in promotion experiences among less educated workers in Australia, we find that women without bachelor's degrees are 3.4 percentage points less likely to have been promoted, have received 0.189 fewer promotions and experience 2.3 percent less wage growth than their male peers. Women in our sample with a bachelor's degree, by contrast, are just as likely to have been promoted, have been promoted a similar number of times, and experience similar wage gains to promotions relative to their male peers. The differences between our studies' findings suggest that the labor markets in Australia and Canada for educated and less educated workers function very differently where promotions and gender are concerned.

\section{Conclusion}

Using a large, nationally representative dataset of firms and their employees in Canada with a well-defined measure of promotions, we find that on average women in Canada are less likely to have been promoted and are promoted fewer times than similar men, but this gender difference stems almost entirely from women working in industries and occupations with flatter job ladders and fewer opportunities for promotion. Even after controlling for industry and occupation, however, women in Canada experience an estimated 2.9 percent less wage growth following a promotion than similar men, but substantial heterogeneity exists among women in the wage returns to promotion. Specifically, we find a "family gap" in the wage returns to promotion experienced by women with single women and women with children experiencing wage returns to promotion almost identical to those of their male peers while women with families see their wages fall behind their male peers even as they are promoted. 
Exploring the reasons behind women's lower wage returns to promotion, we find no evidence that these lower returns can be explained by either the "size" of promotions as measured by the increases in hours and supervisory responsibilities that they entail nor by women's participation in on-the-job training. Another possible explanation is that if the burden of domestic production is split unequally, women with families may be less productive when promoted if they devote significant time and energy to non-work related tasks. We find, however, that the family gap in women's wage returns to promotion is most pronounced among high income women who are presumably most able to substitute income for time and energy in domestic production. Still another possibility is that promoted women have worse outside options by virtue of being less mobile than their male peers. While we do find that women appear to be less mobile in the sense that they are more likely to remain with their employer between interviews, we find no evidence — conditional on worker characteristics — that women with families are less mobile than women without families. Thus differences in mobility would not appear to explain the family gap that we observe.

The wage growth penalty following promotions faced by women with families may well be rooted in behavioral factors. Women with families may, for whatever reason, be reluctant to "lean in" and fully engage in demanding careers (Sandberg 2013). Likewise, promoted women may be less willing to negotiate over raises than men (Babcock \& Laschever 2003). Women with families may be particularly unwilling to try to leverage their success into higher earnings if the expectation is that negotiating for higher wages must be accompanied by greater exertion on the job. We are unable to address these potential explanations with our data, but this highlights an important role for studies using data from a single, non-representative firm. If such data sets have proxies for effort or engagement and the means by which salaries are determined, they could be 
used to shed light on the extent to which these behavioral explanations contribute to the gender gap in the wage returns to promotions. We leave this for future research.

Finally, our findings highlight the importance of gender differences in outcomes in internal labor markets in Canada. Gender equity policies aimed at gender differences in wage levels must take into account the fact that such differences emerge over time through gender differences in wage growth. Our findings point to promotions as a potentially important avenue through which gender differences in earnings in Canada emerge over the course of the career. 


\section{References}

Addison, John, Orgul Ozturk and Si Wang. 2014. "Job Promotion in Mid-Career: Gender, 'Crowding,' and Recession.” Monthly Labor Review, forthcoming.

Addison, John, Orgul Ozturk and Si Wang. 2015. "The Role of Gender in Promotion and Pay over a Career." Journal of Human Capital, 8(3), 280-317.

Albrecht, James, Anders Bjorklund, and Susan Vroman. 2003. "Is There a Glass Ceiling in Sweden?" Journal of Labor Economics, 21, 145-77.

Arulampalam, Wiji, Alison L. Booth, and Mark L. Bryan. 2007. "Is There a Glass Ceiling over Europe? Exploring the Gender Pay Gap Across the Wages Distribution." Industrial \& Labor Relations Review, 60(2), 163-186.

Babcock, Linda and Sara Laschever. 2003. Women Don't Ask: Negotiation and the Gender Divide. Princeton, NJ: Princeton University Press.

Bayard, Kimberly, Judith Hellerstein, David Neumark, and Kenneth Troske. 2003. "New Evidence on Sex Segregation and Sex Differences in Wages from Matched EmployeeEmployer Data." Journal of Labor Economics, 21(4), 887-922.

Becker, Gary. 1985. "Human Capital, Effort, and the Sexual Division of Labor." Journal of Labor Economics, 3, 33-58.

Bertrand, Marianne and Kevin Hallock. 2001. "The gender gap in top corporate jobs." Industrial and Labor Relations Review, 55, 3-21.

Blau, Francine and Jed DeVaro. 2007. "New evidence on gender differences in promotion rates: An empirical analysis of a sample of new hires." Industrial Relations, 46(3), 511-550

Booth, Alison, Marco Francesconi, and Jeff Frank. 2003. "A sticky floors model of promotion, pay, and gender." European Economic Review, 47, 295-322.

Carrington, William J. and Kenneth R. Troske. 1995. "Gender Segregation in Small Firms." Journal of Human Resources, 30(3), 503-33.

Cassidy, Hugh, Jed DeVaro, and Antti Kauhanen. 2012. "The Signaling Role of Promotions: New Evidence from European Firms." Working paper.

Cobb-Clark, Deborah. 2001. "Getting ahead: The determinants of and payoffs to internal promotion for young U.S. men and women." In Worker Well-being in a Changing Labor Market, Research in Labor Economics, edited by Solomon W. Polacheck, 20:339-372.

DeVaro, Jed and Dana Brookshire. 2007. "Promotions and incentives in nonprofit and for-profit organizations." Industrial and Labor Relations Review, 60, 311-339.

Gerhart, Barry and George Milkovich. 1989. "Salaries, Salary Growth, and Promotions of Men and Women in a Large, Private Firm." In Pay Equity: Empirical Inquiries, edited by 
Robert T. Michael, Heidi I. Hartmann, and Brigid O'Farrell, pp. 23-43. Washington, DC: National Academy Press.

Groshen, Erica. 1991. "The Structure of the Female/Male Wage Differential: Is it who you are, what you do, or where you work?” Journal of Human Resources, 26(3), 457-472.

Hersch, Joni and W. Kip Viscusi. 1996. "Gender Differences in Promotions and Wages." Industrial Relations, 35(4), 461-472.

Javdani, Mohsen. 2015. "Glass Ceilings or Glass Doors? The Role of Firms in Male-Female Wage Disparities." forthcoming in the Canadian Journal of Economics.

Johnston, David and Wang-Sheng Lee. 2012. "Climbing the Job Ladder: New Evidence of Gender Inequity." Industrial Relations, 51: 129-151.

Kunze, Astrid. 2014. “The Family Gap in Career Progression.” IZA Discussion Paper No. 8478.

Lazear, Edward and Sherwin Rosen. 1990. "Male-Female Wage Differentials in Job Ladders." Journal of Labor Economics, 8(1), 106-123.

Lewis, Gregory. 1986. "Gender and Promotions: Promotion Chances of White Men and Women in Federal White-Collar Employment." Journal of Human Resources, 21(3), 406-419.

Matsa, David and Amalia Miller. 2011. "Chipping Away at the Glass Ceiling: Gender Spillovers in Corporate Leadership." American Economic Review Papers and Proceedings, 101 (2), $635-639$.

Manning, Alan and Joanna Swaffield. 2008. "The gender gap in early-career wage growth." Economic Journal, 188(530), 983-1024.

McCue, Kristin. 1996. "Promotions and Wage Growth." Journal of Labor Economics, 14, 175209.

Olson, Craig and Brian Becker. 1983. "Sex Discrimination in the Promotion Process." Industrial and Labor Relations Review, 36(4), 276-295.

Paulin, Elizabeth and Jennifer Mellor. 1996. "Gender, Race, and Promotions within a PrivateSector Firm.” Industrial Relations, 35(2), 276-295.

Pergamit, Michael R. and Jonathan R. Veum. 1999. "What is a Promotion?" Industrial and Labor Relations Review, 52(4), 581-601.

Phipps, Shelly, Peter Burton, and Lynn Lethbridge. 2001. "In and out of Labour Market: Longterm income consequences of Child-related interruptions to women's paid work." Canadian Journal of Economics, 34(2), 411-429.

Ransom, Michael and Ronald Oaxaca. 2005. "Intrafirm Mobility and Sex Differences in Pay." Industrial and Labor Relations Review, 58(2), 219-237.

Reilly, Kevin T. and Tony S. Wirjanto. 1999. "Does More Mean Less? The Male/Female Wage Gap and the Proportion of Females at the Establishment Level." Canadian Journal of Economics, 32(4), 906-929. 
Sandberg, Sheryl. 2013. Lean In: Women, Work, and the Will to Lead. New York: Random House.

Smith, Nina, Valdemar Smith, and Mette Verner. 2013. "Why are so Few Females Promoted into CEO and Vice President Positions? Danish Empirical Evidence, 1997-2007." Industrial and Labor Relations Review, 66(2), 2013.

Sorensen, Elaine. 1990. "The Crowding Hypothesis and Comparable Worth." Journal of Human Resources, 25(1), 55-89.

Spurr, Stephen. 1990. "Sex Discrimination in the Legal Profession: A Study of Promotion." Industrial and Labor Relations Review, 43(4), 406-417.

Waldfogel, Jane. 1998. "Understanding the 'Family Gap' in Pay for Women with Children." Journal of Economic Perspectives, 12 (Winter), 137-156.

Winter-Ebmer, Rudolf and Josef Zweimuller. 1997. "Unequal Assignment and Unequal Promotion in Job Ladders." Journal of Labor Economics, 15(1), Part 1: 43-71.

Yap, Margaret and Alison Konrad. 2009. "Gender and Racial Differentials in Promotions: Is there a Sticky Floor, a Mid-Level Bottleneck, or a Glass Ceiling?" Relations Industrielles /Industrial Relations, 64(4), 593-619. 
Table 1: Summary statistics

\begin{tabular}{|c|c|c|c|c|c|c|}
\hline \multirow[b]{2}{*}{ Variable } & \multicolumn{3}{|c|}{ Men } & \multicolumn{3}{|c|}{ Women } \\
\hline & All & Non-promoted & Promoted & All & Non-promoted & Promoted \\
\hline Promoted in past year & 0.27 & 0 & 1 & 0.24 & 0 & 1 \\
\hline Number of promotions with & 1.40 & 0.82 & 2.98 & 1.11 & 0.67 & 2.49 \\
\hline employer & $(2.13)$ & $(1.61)$ & $(2.54)$ & $(1.66)$ & $(1.30)$ & $(1.89)$ \\
\hline Change in log-hourly wage & 0.042 & 0.034 & 0.065 & 0.032 & 0.029 & 0.041 \\
\hline between interviews & $(0.204)$ & $(0.202)$ & $(0.205)$ & $(0.188)$ & $(0.170)$ & $(0.237)$ \\
\hline White, Canadian-born & 0.77 & 0.77 & 0.78 & 0.78 & 0.77 & 0.81 \\
\hline Visible minority, Canadian-born & 0.02 & 0.02 & 0.02 & 0.02 & 0.02 & 0.02 \\
\hline White immigrant & 0.11 & 0.11 & 0.11 & 0.10 & 0.10 & 0.10 \\
\hline Visible minority immigrant & 0.08 & 0.09 & 0.07 & 0.08 & 0.09 & 0.06 \\
\hline Language at home English & 0.67 & 0.66 & 0.71 & 0.70 & 0.68 & 0.76 \\
\hline Language at home French & 0.25 & 0.26 & 0.22 & 0.22 & 0.23 & 0.18 \\
\hline Language at home other & 0.08 & 0.09 & 0.07 & 0.08 & 0.09 & 0.06 \\
\hline \multicolumn{7}{|l|}{ Education: } \\
\hline $\mathrm{MA}, \mathrm{PhD}$ or $\mathrm{MD}$ & 0.05 & 0.05 & 0.05 & 0.04 & 0.04 & 0.05 \\
\hline Other graduate degree & 0.02 & 0.02 & 0.02 & 0.02 & 0.02 & 0.02 \\
\hline Bachelor's degree & 0.14 & 0.13 & 0.16 & 0.13 & 0.13 & 0.14 \\
\hline Some university & 0.08 & 0.08 & 0.10 & 0.09 & 0.09 & 0.10 \\
\hline College or vocational diploma & 0.16 & 0.16 & 0.16 & 0.24 & 0.23 & 0.26 \\
\hline Some college/vocational training & 0.27 & 0.27 & 0.25 & 0.22 & 0.22 & 0.24 \\
\hline High school graduate & 0.16 & 0.16 & 0.17 & 0.17 & 0.17 & 0.15 \\
\hline Less than high school & 0.12 & 0.13 & 0.09 & 0.07 & 0.08 & 0.05 \\
\hline \multicolumn{7}{|l|}{ Marital status: } \\
\hline Married & 0.64 & 0.66 & 0.60 & 0.56 & 0.57 & 0.53 \\
\hline Common law & 0.13 & 0.13 & 0.14 & 0.14 & 0.13 & 0.16 \\
\hline Separated & 0.03 & 0.03 & 0.02 & 0.03 & 0.03 & 0.03 \\
\hline Divorced & 0.04 & 0.04 & 0.03 & 0.09 & 0.09 & 0.08 \\
\hline Widowed & 0.00 & 0.00 & 0.00 & 0.01 & 0.02 & 0.01 \\
\hline Single & 0.16 & 0.14 & 0.21 & 0.17 & 0.16 & 0.20 \\
\hline \multicolumn{7}{|l|}{ Number of children: } \\
\hline None & 0.46 & 0.45 & 0.49 & 0.53 & 0.53 & 0.52 \\
\hline One & 0.18 & 0.18 & 0.17 & 0.19 & 0.19 & 0.19 \\
\hline Two & 0.26 & 0.27 & 0.25 & 0.22 & 0.22 & 0.21 \\
\hline Three & 0.08 & 0.09 & 0.07 & 0.05 & 0.05 & 0.05 \\
\hline Four or more & 0.02 & 0.02 & 0.02 & 0.01 & 0.01 & 0.01 \\
\hline \multicolumn{7}{|l|}{ Age: } \\
\hline $19-24$ & 0.03 & 0.02 & 0.06 & 0.05 & 0.04 & 0.08 \\
\hline $25-29$ & 0.09 & 0.07 & 0.14 & 0.09 & 0.08 & 0.13 \\
\hline $30-34$ & 0.13 & 0.13 & 0.14 & 0.11 & 0.10 & 0.15 \\
\hline $35-39$ & 0.16 & 0.16 & 0.18 & 0.15 & 0.15 & 0.17 \\
\hline $40-44$ & 0.17 & 0.17 & 0.17 & 0.19 & 0.19 & 0.18 \\
\hline $45-49$ & 0.15 & 0.16 & 0.12 & 0.17 & 0.17 & 0.16 \\
\hline $50-54$ & 0.13 & 0.15 & 0.09 & 0.13 & 0.15 & 0.08 \\
\hline $55-59$ & 0.08 & 0.09 & 0.06 & 0.08 & 0.09 & 0.05 \\
\hline $60-64$ & 0.04 & 0.04 & 0.02 & 0.03 & 0.04 & 0.01 \\
\hline \multirow{2}{*}{ Years of work experience } & 20.27 & 21.06 & 18.10 & 17.63 & 18.16 & 15.97 \\
\hline & $(10.48)$ & $(10.46)$ & $(10.23)$ & $(9.72)$ & $(9.76)$ & $(9.39)$ \\
\hline Job part of a CBA or union & 0.28 & 0.31 & 0.20 & 0.28 & 0.31 & 0.18 \\
\hline Number of observations & 24,192 & 17,835 & 6,357 & 16,654 & 12,382 & 4,272 \\
\hline
\end{tabular}

Note: Standard deviations in parentheses. All summary statistics use sample weights provided by Statistics Canada. 
Table 1 continued: Summary statistics

\begin{tabular}{|c|c|c|c|c|c|c|}
\hline Variable & All & $\begin{array}{c}\text { Men } \\
\text { Non-promoted }\end{array}$ & Promoted & All & $\begin{array}{c}\text { Women } \\
\text { Non-promoted }\end{array}$ & Promoted \\
\hline \multicolumn{7}{|l|}{ Industry } \\
\hline Resources & 0.03 & 0.03 & 0.03 & 0.01 & 0.01 & 0.02 \\
\hline $\begin{array}{l}\text { Labor-intensive tertiary } \\
\text { manufacturing }\end{array}$ & 0.06 & 0.06 & 0.06 & 0.05 & 0.05 & 0.04 \\
\hline $\begin{array}{l}\text { Secondary product } \\
\text { manufacturing }\end{array}$ & 0.06 & 0.06 & 0.07 & 0.03 & 0.03 & 0.03 \\
\hline $\begin{array}{l}\text { Capital-intensive tertiary } \\
\text { manufacturing }\end{array}$ & 0.08 & 0.08 & 0.08 & 0.04 & 0.04 & 0.04 \\
\hline Construction & 0.07 & 0.07 & 0.08 & 0.02 & 0.02 & 0.01 \\
\hline Transportation & 0.15 & 0.15 & 0.15 & 0.08 & 0.08 & 0.09 \\
\hline $\begin{array}{l}\text { Communication and other } \\
\text { utilities }\end{array}$ & 0.03 & 0.03 & 0.03 & 0.01 & 0.01 & 0.02 \\
\hline Retail & 0.16 & 0.16 & 0.16 & 0.20 & 0.19 & 0.22 \\
\hline Finance and insurance & 0.03 & 0.03 & 0.04 & 0.07 & 0.07 & 0.11 \\
\hline Real estate & 0.02 & 0.02 & 0.02 & 0.01 & 0.01 & 0.02 \\
\hline Business services & 0.10 & 0.09 & 0.12 & 0.11 & 0.10 & 0.13 \\
\hline Education and health services & 0.11 & 0.12 & 0.07 & 0.32 & 0.35 & 0.22 \\
\hline $\begin{array}{l}\text { Information and cultural } \\
\text { industries }\end{array}$ & 0.04 & 0.03 & 0.05 & 0.03 & 0.03 & 0.05 \\
\hline $\begin{array}{l}\text { Primary product manufacturing } \\
\text { Occupation }\end{array}$ & 0.06 & 0.06 & 0.06 & 0.02 & 0.02 & 0.02 \\
\hline Managers & 0.19 & 0.18 & 0.22 & 0.12 & 0.10 & 0.17 \\
\hline Professionals & 0.15 & 0.14 & 0.17 & 0.21 & 0.21 & 0.19 \\
\hline Technical trade & 0.52 & 0.53 & 0.49 & 0.33 & 0.33 & 0.34 \\
\hline Marketing \& sales & 0.02 & 0.03 & 0.02 & 0.07 & 0.07 & 0.05 \\
\hline Clerical \& administrative & 0.06 & 0.07 & 0.05 & 0.23 & 0.23 & 0.21 \\
\hline Usual hours per week worked & $\begin{array}{l}41.07 \\
(5.77)\end{array}$ & $\begin{array}{l}41.06 \\
(6.01)\end{array}$ & $\begin{array}{l}41.09 \\
(5.08)\end{array}$ & $\begin{array}{l}37.95 \\
(4.29)\end{array}$ & $\begin{array}{l}37.69 \\
(4.09)\end{array}$ & $\begin{array}{l}38.75 \\
(7.49)\end{array}$ \\
\hline Weeks worked per year & $\begin{array}{l}51.12 \\
(3.82)\end{array}$ & $\begin{array}{l}51.04 \\
(4.03)\end{array}$ & $\begin{array}{l}51.33 \\
(3.18)\end{array}$ & $\begin{array}{l}51.27 \\
(3.52)\end{array}$ & $\begin{array}{l}51.21 \\
(3.69)\end{array}$ & $\begin{array}{l}51.47 \\
(2.91)\end{array}$ \\
\hline Number of employees supervised & $\begin{array}{l}8.95 \\
(46.38)\end{array}$ & $\begin{array}{l}7.33 \\
(37.85)\end{array}$ & $\begin{array}{l}13.37 \\
(63.91)\end{array}$ & $\begin{array}{l}4.92 \\
(71.32)\end{array}$ & $\begin{array}{l}3.41 \\
(18.94)\end{array}$ & $\begin{array}{l}9.69 \\
(141.36)\end{array}$ \\
\hline Unpaid overtime hours per week & $\begin{array}{l}2.45 \\
(5.34)\end{array}$ & $\begin{array}{l}2.25 \\
(5.20)\end{array}$ & $\begin{array}{l}3.00 \\
(5.66)\end{array}$ & $\begin{array}{l}1.90 \\
(4.30)\end{array}$ & $\begin{array}{l}1.63 \\
(3.97)\end{array}$ & $\begin{array}{l}2.75 \\
(5.11)\end{array}$ \\
\hline$\Delta$ in usual hours per week worked & $\begin{array}{l}0.17 \\
(5.42)\end{array}$ & $\begin{array}{l}0.21 \\
(5.49)\end{array}$ & $\begin{array}{l}0.05 \\
(5.24)\end{array}$ & $\begin{array}{l}0.63 \\
(4.93)\end{array}$ & $\begin{array}{l}0.62 \\
(5.00)\end{array}$ & $\begin{array}{l}0.67 \\
(4.69)\end{array}$ \\
\hline$\Delta$ in weeks worked per year & $\begin{array}{l}-0.04 \\
(3.54)\end{array}$ & $\begin{array}{l}-0.04 \\
(3.66)\end{array}$ & $\begin{array}{l}-0.02 \\
(3.21)\end{array}$ & $\begin{array}{l}0.04 \\
(3.08)\end{array}$ & $\begin{array}{l}0.06 \\
(3.16)\end{array}$ & $\begin{array}{l}-0.04 \\
(2.82)\end{array}$ \\
\hline$\Delta$ in number of employees supervised & $\begin{array}{l}-0.74 \\
(67.73)\end{array}$ & $\begin{array}{l}-1.28 \\
(69.59)\end{array}$ & $\begin{array}{l}0.74 \\
(62.35)\end{array}$ & $\begin{array}{l}1.01 \\
(71.99)\end{array}$ & $\begin{array}{l}-0.23 \\
(22.84)\end{array}$ & $\begin{array}{l}4.94 \\
(141.00)\end{array}$ \\
\hline$\Delta$ in unpaid overtime hours per week & $\begin{array}{l}0.03 \\
(5.64)\end{array}$ & $\begin{array}{l}-0.06 \\
(5.50)\end{array}$ & $\begin{array}{l}0.28 \\
(6.00)\end{array}$ & $\begin{array}{l}0.11 \\
(4.20)\end{array}$ & $\begin{array}{l}-0.04 \\
(4.02)\end{array}$ & $\begin{array}{l}0.60 \\
(4.69)\end{array}$ \\
\hline On-the-job training (OJT) & 0.27 & 0.24 & 0.34 & 0.31 & 0.29 & 0.39 \\
\hline Days of OJT in the previous year & $\begin{array}{l}1.79 \\
(9.99)\end{array}$ & $\begin{array}{l}1.39 \\
(8.97)\end{array}$ & $\begin{array}{l}2.91 \\
(12.29)\end{array}$ & $\begin{array}{l}1.54 \\
(7.84)\end{array}$ & $\begin{array}{l}1.26 \\
(6.46)\end{array}$ & $\begin{array}{l}2.42 \\
(11.09)\end{array}$ \\
\hline Declined OJT through employer & 0.12 & 0.11 & 0.15 & 0.13 & 0.13 & 0.14 \\
\hline Training not through employer & 0.06 & 0.05 & 0.06 & 0.07 & 0.07 & 0.06 \\
\hline Number of observations & 24,192 & 17,835 & 6,357 & 16,654 & 12,382 & 4,272 \\
\hline
\end{tabular}


Table 2: Marginal effects of gender on promotion outcomes and log-wage growth

\begin{tabular}{|c|c|c|c|c|c|c|c|c|}
\hline Variable & $(1)$ & $(2)$ & $(3)$ & $(4)$ & $(5)$ & (6) & $(7)$ & $(8)$ \\
\hline Panel A: & \multicolumn{8}{|c|}{ Dependent variable: Whether promoted between interviews } \\
\hline 1 if female & $\begin{array}{l}-0.028 * * * \\
(0.010)\end{array}$ & $\begin{array}{l}-0.031 * * * \\
(0.010)\end{array}$ & $\begin{array}{l}-0.019^{*} \\
(0.011)\end{array}$ & $\begin{array}{l}-0.022 * * \\
(0.011)\end{array}$ & $\begin{array}{l}-0.007 \\
(0.011)\end{array}$ & $\begin{array}{l}-0.008 \\
(0.013)\end{array}$ & & \\
\hline Panel B: & \multicolumn{8}{|c|}{ Dependent variable: Number of times promoted with current employer in year $t+1$} \\
\hline 1 if female & $\begin{array}{l}-0.293 * * * \\
(0.038)\end{array}$ & $\begin{array}{l}-0.244 * * * \\
(0.039)\end{array}$ & $\begin{array}{l}-0.161 * * * \\
(0.041)\end{array}$ & $\begin{array}{l}-0.176 * * * \\
(0.039)\end{array}$ & $\begin{array}{l}-0.074^{*} \\
(0.040)\end{array}$ & $\begin{array}{l}-0.089 * \\
(0.049)\end{array}$ & & \\
\hline Panel C: & \multicolumn{8}{|c|}{ Dependent variable: Log-wage growth between interviews } \\
\hline 1 if female and promoted & $\begin{array}{l}-0.024 * \\
(0.014)\end{array}$ & $\begin{array}{l}-0.027 * * \\
(0.013)\end{array}$ & $\begin{array}{l}-0.028 * * \\
(0.013)\end{array}$ & $\begin{array}{l}-0.028 * * \\
(0.014)\end{array}$ & $\begin{array}{l}-0.028 * * \\
(0.013)\end{array}$ & $\begin{array}{l}-0.029^{*} \\
(0.015)\end{array}$ & $\begin{array}{l}-0.027^{*} \\
(0.015)\end{array}$ & $\begin{array}{l}-0.029^{*} \\
(0.015)\end{array}$ \\
\hline 1 if female and not promoted & $\begin{array}{l}-0.005 \\
(0.005)\end{array}$ & $\begin{array}{l}-0.009^{*} \\
(0.005)\end{array}$ & $\begin{array}{l}-0.010 * * \\
(0.005)\end{array}$ & $\begin{array}{l}-0.011 * * \\
(0.005)\end{array}$ & $\begin{array}{l}-0.011 * * \\
(0.005)\end{array}$ & $\begin{array}{l}-0.016^{* *} \\
(0.007)\end{array}$ & $\begin{array}{l}-0.016^{* *} \\
(0.007)\end{array}$ & $\begin{array}{l}-0.016^{* *} \\
(0.007)\end{array}$ \\
\hline 1 if promoted & $\begin{array}{l}0.031 * * * \\
(0.006)\end{array}$ & $\begin{array}{l}0.027 * * * \\
(0.006)\end{array}$ & $\begin{array}{l}0.026^{* * * *} \\
(0.006)\end{array}$ & $\begin{array}{l}0.026^{* * *} \\
(0.006)\end{array}$ & $\begin{array}{l}0.025 * * * \\
(0.006)\end{array}$ & $\begin{array}{l}0.028 * * * \\
(0.007)\end{array}$ & $\begin{array}{l}0.027 * * * \\
(0.007)\end{array}$ & $\begin{array}{l}0.027 * * * \\
(0.007)\end{array}$ \\
\hline Controls: & & & & & & & & \\
\hline Worker characteristics & & $\mathrm{X}$ & $\mathrm{x}$ & $\mathrm{X}$ & $\mathrm{X}$ & $x$ & $x$ & $\mathrm{X}$ \\
\hline Industry & & & $x$ & & $x$ & & & \\
\hline Occupation & & & & $\mathrm{x}$ & $x$ & $\mathrm{X}$ & $x$ & $x$ \\
\hline Firm fixed effects & & & & & & $x$ & $x$ & $x$ \\
\hline Hours \& supervisory responsibilities & & & & & & & $x$ & \\
\hline Participation in training & & & & & & & & $x$ \\
\hline
\end{tabular}

* - significant at the $10 \%$ level, ** - significant at the $5 \%$ level, *** - significant at the $1 \%$ level

Note: The standard errors in parentheses are robust to clustering at the firm level. The sample consists of observations from 40,846 workers. The worker-level characteristics include indicators for visible minority and immigrant status, education level, marital status, number of children, age, whether the job is part of a union or falls under a collective bargaining agreement, and years of experience (the variables described in table 1). The industry controls include 14 indicators for different industries, and the occupation controls include five indicators for broad occupational categories. The hours and supervisory responsibilities controls include usual hours worked per week, weeks worked per year, the number of employees supervised, and hours of unpaid overtime per week in year $t+1$ as well as the changes in these variables between interviews. The participation in training controls include indicators for whether the worker received on-the-job training in the previous year, whether the worker elected not to participate in OJT, whether the worker received training not through the employer and the number of days spent in on-the-job training in the previous year. 
Table 3: The "family gap" in promotion experiences

\begin{tabular}{|c|c|c|c|c|c|c|}
\hline & $(1)$ & $(2)$ & $(3)$ & $(4)$ & $(5)$ & $(6)$ \\
\hline Panel A: & \multicolumn{6}{|c|}{ Dependent variable: Whether promoted between interviews } \\
\hline 1 if married female & $\begin{array}{l}-0.033^{* * *} \\
(0.010)\end{array}$ & $\begin{array}{l}-0.025^{* *} \\
(0.010)\end{array}$ & $\begin{array}{l}-0.013 \\
(0.011)\end{array}$ & $\begin{array}{l}-0.016 \\
(0.010)\end{array}$ & $\begin{array}{l}-0.001 \\
(0.011)\end{array}$ & $\begin{array}{l}-0.002 \\
(0.013)\end{array}$ \\
\hline 1 if single female & $\begin{array}{l}-0.007 \\
(0.023)\end{array}$ & $\begin{array}{l}-0.047 * * \\
(0.023)\end{array}$ & $\begin{array}{l}-0.037 \\
(0.023)\end{array}$ & $\begin{array}{l}-0.041^{*} \\
(0.023)\end{array}$ & $\begin{array}{l}-0.028 \\
(0.024)\end{array}$ & $\begin{array}{l}-0.029 \\
(0.023)\end{array}$ \\
\hline & \multicolumn{6}{|c|}{ Dependent variable: Number of times promoted with current employer in $\mathrm{t}+1$} \\
\hline 1 if married female & $\begin{array}{l}-0.298 * * * \\
(0.039)\end{array}$ & $\begin{array}{l}-0.251 * * * \\
(0.040)\end{array}$ & $\begin{array}{l}-0.166 * * * \\
(0.042)\end{array}$ & $\begin{array}{l}-0.178 * * * \\
(0.041)\end{array}$ & $\begin{array}{l}-0.074 * \\
(0.042)\end{array}$ & $\begin{array}{l}-0.101^{* *} \\
(0.050)\end{array}$ \\
\hline 1 if single female & $\begin{array}{l}-0.274 * * * \\
(0.071)\end{array}$ & $\begin{array}{l}-0.205 * * * \\
(0.076)\end{array}$ & $\begin{array}{l}-0.131^{*} \\
(0.076)\end{array}$ & $\begin{array}{l}-0.158^{* *} \\
(0.073)\end{array}$ & $\begin{array}{l}-0.067 \\
(0.071)\end{array}$ & $\begin{array}{l}-0.041 \\
(0.083)\end{array}$ \\
\hline & \multicolumn{6}{|c|}{ Dependent variable: Log-wage growth between interviews } \\
\hline 1 if single female \& promoted & $\begin{array}{l}0.025^{*} \\
(0.015)\end{array}$ & $\begin{array}{l}0.025 \\
(0.016)\end{array}$ & $\begin{array}{l}0.025 \\
(0.016)\end{array}$ & $\begin{array}{l}0.024 \\
(0.016)\end{array}$ & $\begin{array}{l}0.025 \\
(0.016)\end{array}$ & $\begin{array}{l}0.017 \\
(0.017)\end{array}$ \\
\hline 1 if married female \& promoted & $\begin{array}{l}-0.038 * * \\
(0.017)\end{array}$ & $\begin{array}{l}-0.041 * * * \\
(0.015)\end{array}$ & $\begin{array}{l}-0.042 * * * \\
(0.015)\end{array}$ & $\begin{array}{l}-0.043 * * * \\
(0.016)\end{array}$ & $\begin{array}{l}-0.043^{* * * *} \\
(0.016)\end{array}$ & $\begin{array}{l}-0.042 * * \\
(0.017)\end{array}$ \\
\hline 1 if single female $\&$ not promoted & $\begin{array}{l}0.003 \\
(0.007)\end{array}$ & $\begin{array}{l}0.004 \\
(0.009)\end{array}$ & $\begin{array}{l}0.003 \\
(0.009)\end{array}$ & $\begin{array}{l}0.001 \\
(0.010)\end{array}$ & $\begin{array}{l}0.001 \\
(0.010)\end{array}$ & $\begin{array}{l}-0.013 \\
(0.013)\end{array}$ \\
\hline 1 if married female \& not promoted & $\begin{array}{l}-0.006 \\
(0.005)\end{array}$ & $\begin{array}{l}-0.011^{* *} \\
(0.005)\end{array}$ & $\begin{array}{l}-0.013 * * \\
(0.005)\end{array}$ & $\begin{array}{l}-0.014 * * * \\
(0.005)\end{array}$ & $\begin{array}{l}-0.014^{* * * *} \\
(0.005)\end{array}$ & $\begin{array}{l}-0.017^{* *} \\
(0.007)\end{array}$ \\
\hline Panel B: & \multicolumn{6}{|c|}{ Dependent variable: Whether promoted between interviews } \\
\hline 1 if female with children & $\begin{array}{l}-0.026^{* *} \\
(0.012)\end{array}$ & $\begin{array}{l}-0.023^{*} \\
(0.012)\end{array}$ & $\begin{array}{l}-0.010 \\
(0.013)\end{array}$ & $\begin{array}{l}-0.015 \\
(0.013)\end{array}$ & $\begin{array}{l}0.001 \\
(0.013)\end{array}$ & $\begin{array}{l}-0.001 \\
(0.015)\end{array}$ \\
\hline 1 if childless female & $\begin{array}{l}-0.030^{* *} \\
(0.013)\end{array}$ & $\begin{array}{l}-0.036^{* * *} \\
(0.012)\end{array}$ & $\begin{array}{l}-0.024^{*} \\
(0.013)\end{array}$ & $\begin{array}{l}-0.027 * * \\
(0.013)\end{array}$ & $\begin{array}{l}-0.013 \\
(0.013)\end{array}$ & $\begin{array}{l}-0.013 \\
(0.014)\end{array}$ \\
\hline & \multicolumn{6}{|c|}{ Dependent variable: Number of times promoted with current employer in $\mathrm{t}+1$} \\
\hline 1 if female with children & $\begin{array}{l}-0.268 * * * \\
(0.046)\end{array}$ & $\begin{array}{l}-0.236 * * * \\
(0.048)\end{array}$ & $\begin{array}{l}-0.149 * * * \\
(0.049)\end{array}$ & $\begin{array}{l}-0.172 * * * \\
(0.047)\end{array}$ & $\begin{array}{l}-0.066 \\
(0.049)\end{array}$ & $\begin{array}{l}-0.098^{*} \\
(0.058)\end{array}$ \\
\hline 1 if childless female & $\begin{array}{l}-0.315^{* * *} \\
(0.046)\end{array}$ & $\begin{array}{l}-0.248^{* * * *} \\
(0.046)\end{array}$ & $\begin{array}{l}-0.169^{* * *} \\
(0.048)\end{array}$ & $\begin{array}{l}-0.176^{* * * *} \\
(0.045)\end{array}$ & $\begin{array}{l}-0.078^{*} \\
(0.047)\end{array}$ & $\begin{array}{l}-0.081 \\
(0.053)\end{array}$ \\
\hline & \multicolumn{6}{|c|}{ Dependent variable: Log-wage growth between interviews } \\
\hline 1 if childless female \& promoted & $\begin{array}{l}0.003 \\
(0.010)\end{array}$ & $\begin{array}{l}0.002 \\
(0.010)\end{array}$ & $\begin{array}{l}0.0002 \\
(0.010)\end{array}$ & $\begin{array}{l}-0.0001 \\
(0.010)\end{array}$ & $\begin{array}{l}-0.0003 \\
(0.010)\end{array}$ & $\begin{array}{l}-0.001 \\
(0.011)\end{array}$ \\
\hline $\begin{array}{l}1 \text { if female with children \& } \\
\text { promoted }\end{array}$ & $\begin{array}{l}-0.053 * * \\
(0.025)\end{array}$ & $\begin{array}{l}-0.057 * * \\
(0.023)\end{array}$ & $\begin{array}{l}-0.057 * * \\
(0.023)\end{array}$ & $\begin{array}{l}-0.059 * * \\
(0.024)\end{array}$ & $\begin{array}{l}-0.058 * * \\
(0.023)\end{array}$ & $\begin{array}{l}-0.059 * * \\
(0.025)\end{array}$ \\
\hline 1 if childless female \& not promoted & $\begin{array}{l}-0.003 \\
(0.005)\end{array}$ & $\begin{array}{l}-0.003 \\
(0.006)\end{array}$ & $\begin{array}{l}-0.004 \\
(0.007)\end{array}$ & $\begin{array}{l}-0.005 \\
(0.006)\end{array}$ & $\begin{array}{l}-0.005 \\
(0.007)\end{array}$ & $\begin{array}{l}-0.015^{*} \\
(0.008)\end{array}$ \\
\hline $\begin{array}{l}1 \text { if female with children \& not } \\
\text { promoted }\end{array}$ & $\begin{array}{l}-0.006 \\
(0.006)\end{array}$ & $\begin{array}{l}-0.013 * * \\
(0.006)\end{array}$ & $\begin{array}{l}-0.015^{* *} \\
(0.006)\end{array}$ & $\begin{array}{l}-0.016^{* *} \\
(0.006)\end{array}$ & $\begin{array}{l}-0.016^{* *} \\
(0.006)\end{array}$ & $\begin{array}{l}-0.016^{*} \\
(0.009)\end{array}$ \\
\hline Controls: & & & & & & \\
\hline Worker characteristics & & $\mathrm{x}$ & $\mathrm{x}$ & $\mathrm{x}$ & $\mathrm{x}$ & $\mathrm{x}$ \\
\hline Industry & & & $\mathrm{x}$ & & $\mathrm{x}$ & \\
\hline Occupation & & & & $\mathrm{x}$ & $x$ & $\mathrm{x}$ \\
\hline Firm fixed effects & & & & & & $x$ \\
\hline
\end{tabular}

* - significant at the 10\% level, ** - significant at the 5\% level, *** - significant at the $1 \%$ level

Note: The standard errors in parentheses are robust to clustering at the firm level. The sample consists of observations from 40,846 workers. The controls are as described in the note to table 2 . 
Table 4: Estimated wage returns to promotion by gender and income quartile

\begin{tabular}{|c|c|c|c|c|c|}
\hline Variable & $\begin{array}{c}\text { (1) } \\
\text { Full sample }\end{array}$ & $\begin{array}{c}(2) \\
\text { Bottom } \\
\text { quartile }\end{array}$ & $\begin{array}{c}\text { (3) } \\
\text { Lower middle } \\
\text { quartile }\end{array}$ & $\begin{array}{c}\text { (4) } \\
\text { Upper middle } \\
\text { quartile }\end{array}$ & $\begin{array}{c}(5) \\
\text { Top } \\
\text { quartile }\end{array}$ \\
\hline Panel A: & \multicolumn{5}{|c|}{ All workers } \\
\hline 1 if female and promoted & $\begin{array}{l}-0.029 * \\
(0.015)\end{array}$ & $\begin{array}{l}-0.081 * * * \\
(0.019)\end{array}$ & $\begin{array}{l}-0.044 * * * \\
(0.015)\end{array}$ & $\begin{array}{l}-0.033^{* *} \\
(0.014)\end{array}$ & $\begin{array}{l}-0.068 * \\
(0.040)\end{array}$ \\
\hline 1 if female and not promoted & $\begin{array}{l}-0.016 * * \\
(0.007)\end{array}$ & $\begin{array}{l}-0.036 * * * \\
(0.013)\end{array}$ & $\begin{array}{l}-0.028 * * * \\
(0.009)\end{array}$ & $\begin{array}{l}-0.047 * * * \\
(0.010)\end{array}$ & $\begin{array}{l}-0.034 * * * \\
(0.011)\end{array}$ \\
\hline 1 if promoted & $\begin{array}{l}0.028 * * * \\
(0.007)\end{array}$ & $\begin{array}{l}0.066^{* * * *} \\
(0.016)\end{array}$ & $\begin{array}{l}0.015 \\
(0.013)\end{array}$ & $\begin{array}{l}0.007 \\
(0.010)\end{array}$ & $\begin{array}{l}0.018 \\
(0.013)\end{array}$ \\
\hline Panel B: & \multicolumn{5}{|c|}{ By marital status } \\
\hline 1 if single female $\&$ promoted & $\begin{array}{l}0.017 \\
(0.017)\end{array}$ & $\begin{array}{l}-0.046 \\
(0.028)\end{array}$ & $\begin{array}{l}-0.016 \\
(0.031)\end{array}$ & $\begin{array}{l}0.023 \\
(0.030)\end{array}$ & $\begin{array}{l}0.041 \\
(0.027)\end{array}$ \\
\hline 1 if married female $\&$ promoted & $\begin{array}{l}-0.042 * * \\
(0.017)\end{array}$ & $\begin{array}{l}-0.095 * * * \\
(0.020)\end{array}$ & $\begin{array}{l}-0.053 * * * \\
(0.016)\end{array}$ & $\begin{array}{l}-0.048 * * * \\
(0.014)\end{array}$ & $\begin{array}{l}-0.090 * \\
(0.046)\end{array}$ \\
\hline 1 if single female $\&$ not promoted & $\begin{array}{l}-0.012 \\
(0.012)\end{array}$ & $\begin{array}{l}-0.042 * * \\
(0.018)\end{array}$ & $\begin{array}{l}-0.019 \\
(0.015)\end{array}$ & $\begin{array}{l}-0.020 \\
(0.020)\end{array}$ & $\begin{array}{l}0.011 \\
(0.023)\end{array}$ \\
\hline 1 if married female $\&$ not promoted & $\begin{array}{l}-0.016^{* *} \\
(0.007)\end{array}$ & $\begin{array}{l}-0.036^{* * *} \\
(0.012)\end{array}$ & $\begin{array}{l}-0.033 * * * \\
(0.009)\end{array}$ & $\begin{array}{l}-0.051 * * * \\
(0.011)\end{array}$ & $\begin{array}{l}-0.039 * * * \\
(0.011)\end{array}$ \\
\hline Panel C: & \multicolumn{5}{|c|}{ By the presence of children } \\
\hline 1 if childless female \& promoted & $\begin{array}{l}-0.001 \\
(0.011)\end{array}$ & $\begin{array}{l}-0.066 * * * \\
(0.020)\end{array}$ & $\begin{array}{l}-0.046^{* *} \\
(0.019)\end{array}$ & $\begin{array}{l}0.007 \\
(0.020)\end{array}$ & $\begin{array}{l}0.019 \\
(0.017)\end{array}$ \\
\hline 1 if female with children $\&$ promoted & $\begin{array}{l}-0.059 * * \\
(0.025)\end{array}$ & $\begin{array}{l}-0.099 * * * \\
(0.022)\end{array}$ & $\begin{array}{l}-0.047 * * * \\
(0.017)\end{array}$ & $\begin{array}{l}-0.071 * * * \\
(0.021)\end{array}$ & $\begin{array}{l}-0.157 * * \\
(0.071)\end{array}$ \\
\hline 1 if childless female $\&$ not promoted & $\begin{array}{l}-0.015^{* *} \\
(0.007)\end{array}$ & $\begin{array}{l}-0.035 * * * \\
(0.013)\end{array}$ & $\begin{array}{l}-0.028 * * * \\
(0.010)\end{array}$ & $\begin{array}{l}-0.046 * * * \\
(0.012)\end{array}$ & $\begin{array}{l}-0.039 * * * \\
(0.015)\end{array}$ \\
\hline $\begin{array}{l}1 \text { if female with children } \& \text { not } \\
\text { promoted }\end{array}$ & $\begin{array}{l}-0.015^{*} \\
(0.008)\end{array}$ & $\begin{array}{l}-0.038 * * * \\
(0.015)\end{array}$ & $\begin{array}{l}-0.030 * * * \\
(0.010)\end{array}$ & $\begin{array}{l}-0.047 * * * \\
(0.012)\end{array}$ & $\begin{array}{l}-0.028 * * \\
(0.012)\end{array}$ \\
\hline
\end{tabular}

* - significant at the 10\% level, ** - significant at the 5\% level, *** - significant at the $1 \%$ level

Note: The standard errors in parentheses are robust to clustering at the firm level. The sample consists of observations from 40,846 workers. The first column repeats the estimates from column 6 of table 2 in panel A and column 6 of table 3 in panels B and C. The controls correspond to those in column 6 of table 2 with worker characteristics, indicators for broad occupations, and firm fixed effects. Columns 2-5 interact all controls with indicators for the worker's income quartile in year $t$; the firm effects are constrained to be the same across all income quartiles. 
Table 5: Analysis of transition patterns between interviews

\begin{tabular}{|c|c|c|c|c|}
\hline & $\begin{array}{c}\text { (1) } \\
\text { Remained with } \\
\text { employer in } \mathrm{t}+1\end{array}$ & $\begin{array}{c}\text { (2) } \\
\text { New employer } \\
\text { in } \mathrm{t}+1\end{array}$ & $\begin{array}{c}(3) \\
\text { No employer } \\
\text { in } \mathrm{t}+1\end{array}$ & $\begin{array}{c}\text { (4) } \\
\text { Not interviewed } \\
\text { in } \mathrm{t}+1\end{array}$ \\
\hline Panel A: & \multicolumn{4}{|c|}{ Proportion of sample group in each category } \\
\hline Women & 0.723 & 0.052 & 0.053 & 0.172 \\
\hline Men & 0.703 & 0.054 & 0.044 & 0.199 \\
\hline Single women & 0.661 & 0.069 & 0.051 & 0.219 \\
\hline Married women & 0.741 & 0.047 & 0.054 & 0.158 \\
\hline Single men & 0.609 & 0.086 & 0.059 & 0.246 \\
\hline Married men & 0.731 & 0.045 & 0.039 & 0.185 \\
\hline Women without children & 0.702 & 0.057 & 0.053 & 0.188 \\
\hline Women with children & 0.747 & 0.047 & 0.052 & 0.154 \\
\hline Men without children & 0.662 & 0.065 & 0.056 & 0.217 \\
\hline Men with children & 0.743 & 0.044 & 0.032 & 0.181 \\
\hline Panel B: & \multicolumn{4}{|c|}{$\begin{array}{l}\text { Average marginal effects of group membership on the probability of } \\
\text { each outcome relative to reference group }\end{array}$} \\
\hline \multirow[b]{2}{*}{ Women } & \multicolumn{4}{|c|}{ Reference group: men } \\
\hline & $\begin{array}{l}0.035^{* * *} \\
(0.009)\end{array}$ & $\begin{array}{l}-0.008 * \\
(0.004)\end{array}$ & $\begin{array}{l}0.004 \\
(0.005)\end{array}$ & $\begin{array}{l}-0.031 * * * \\
(0.008)\end{array}$ \\
\hline & \multicolumn{4}{|c|}{ Reference group: married men } \\
\hline Single women & $\begin{array}{l}0.047 * * * \\
(0.017)\end{array}$ & $\begin{array}{l}-0.016^{* *} \\
(0.008)\end{array}$ & $\begin{array}{l}-0.011 \\
(0.008)\end{array}$ & $\begin{array}{l}-0.020 \\
(0.015)\end{array}$ \\
\hline Married women & $\begin{array}{l}0.030 * * * \\
(0.010)\end{array}$ & $\begin{array}{l}-0.003 \\
(0.005)\end{array}$ & $\begin{array}{l}0.008 \\
(0.005)\end{array}$ & $\begin{array}{l}-0.035^{* * *} \\
(0.009)\end{array}$ \\
\hline Single men & $\begin{array}{l}0.020 \\
(0.022)\end{array}$ & $\begin{array}{l}0.007 \\
(0.013)\end{array}$ & $\begin{array}{l}-0.015 \\
(0.014)\end{array}$ & $\begin{array}{l}-0.012 \\
(0.019)\end{array}$ \\
\hline & \multicolumn{4}{|c|}{ Reference group: men with children } \\
\hline Women without children & $\begin{array}{l}0.044 * * * \\
(0.012)\end{array}$ & $\begin{array}{l}-0.010 * \\
(0.006)\end{array}$ & $\begin{array}{l}-0.006 \\
(0.005)\end{array}$ & $\begin{array}{l}-0.028 * * * \\
(0.010)\end{array}$ \\
\hline Women with children & $\begin{array}{l}0.022 * \\
(0.013)\end{array}$ & $\begin{array}{l}-0.004 \\
(0.006)\end{array}$ & $\begin{array}{l}0.018 * * \\
(0.007)\end{array}$ & $\begin{array}{l}-0.036^{* * *} \\
(0.011)\end{array}$ \\
\hline Men without children & $\begin{array}{l}-0.025 * * \\
(0.013)\end{array}$ & $\begin{array}{l}0.007 \\
(0.007)\end{array}$ & $\begin{array}{l}0.008 \\
(0.007)\end{array}$ & $\begin{array}{l}0.011 \\
(0.011)\end{array}$ \\
\hline
\end{tabular}

* - significant at the 10\% level, ** - significant at the 5\% level, *** - significant at the $1 \%$ level

Note: The standard errors in parentheses are robust to clustering at the firm level. The sample consists of observations from 61,923 workers. The lower panel reports average marginal effects from a multinomial logit model of transitions between interviews controlling for worker characteristics, industry, and occupation in year $t+1$. 
Table 6: Heterogeneity in marginal effects of gender on promotion experiences

\begin{tabular}{|c|c|c|c|c|c|}
\hline & $\begin{array}{l}\text { Whether } \\
\text { promoted }\end{array}$ & $\begin{array}{c}\text { (2) } \\
\text { Number of } \\
\text { times } \\
\text { promoted }\end{array}$ & \multicolumn{3}{|c|}{ Log-wage growth } \\
\hline Variable & 1 if female & 1 if female & $\begin{array}{l}1 \text { if female } \\
\& \text { promoted }\end{array}$ & $\begin{array}{c}1 \text { if } \\
\text { promoted }\end{array}$ & $\begin{array}{l}1 \text { if female \& } \\
\text { not promoted }\end{array}$ \\
\hline $\begin{array}{l}\text { Workers in predominantly female } \\
\text { occupations }\end{array}$ & $\begin{array}{l}-0.023 \\
(0.028)\end{array}$ & $\begin{array}{l}-0.087 \\
(0.111)\end{array}$ & $\begin{array}{l}-0.007 \\
(0.025)\end{array}$ & $\begin{array}{l}-0.013 \\
(0.055)\end{array}$ & $\begin{array}{l}-0.026 \\
(0.016)\end{array}$ \\
\hline $\begin{array}{l}\text { Workers in non-predominantly female } \\
\text { occupations }\end{array}$ & $\begin{array}{l}-0.004 \\
(0.014)\end{array}$ & $\begin{array}{l}-0.092 * \\
(0.052)\end{array}$ & $\begin{array}{l}-0.032 * \\
(0.018)\end{array}$ & $\begin{array}{l}0.030 * * * \\
(0.007)\end{array}$ & $\begin{array}{l}-0.016^{* *} \\
(0.008)\end{array}$ \\
\hline Workers with two years or less of tenure & $\begin{array}{l}0.028 \\
(0.041)\end{array}$ & $\begin{array}{l}0.020 \\
(0.114)\end{array}$ & $\begin{array}{l}-0.022 \\
(0.023)\end{array}$ & $\begin{array}{l}0.034 \\
(0.049)\end{array}$ & $\begin{array}{l}-0.031 * * \\
(0.016)\end{array}$ \\
\hline $\begin{array}{l}\text { Workers with more than two years of } \\
\text { tenure }\end{array}$ & $\begin{array}{l}-0.011 \\
(0.013)\end{array}$ & $\begin{array}{l}-0.101^{* *} \\
(0.050)\end{array}$ & $\begin{array}{l}-0.031 * \\
(0.017)\end{array}$ & $\begin{array}{l}0.027 * * * \\
(0.007)\end{array}$ & $\begin{array}{l}-0.014 * \\
(0.007)\end{array}$ \\
\hline Workers 40 and younger & $\begin{array}{l}-0.015 \\
(0.023)\end{array}$ & $\begin{array}{l}-0.180 * * \\
(0.077)\end{array}$ & $\begin{array}{l}-0.029 * \\
(0.015)\end{array}$ & $\begin{array}{l}0.044 * * * \\
(0.012)\end{array}$ & $\begin{array}{l}-0.017 \\
(0.011)\end{array}$ \\
\hline Workers over age 40 & $\begin{array}{l}-0.0004 \\
(0.014)\end{array}$ & $\begin{array}{l}-0.041 \\
(0.056)\end{array}$ & $\begin{array}{l}-0.029 \\
(0.021)\end{array}$ & $\begin{array}{l}-0.018 \\
(0.035)\end{array}$ & $\begin{array}{l}-0.016^{* *} \\
(0.008)\end{array}$ \\
\hline $\begin{array}{l}\text { Workers with less than a bachelor's } \\
\text { degree }\end{array}$ & $\begin{array}{l}-0.016 \\
(0.014)\end{array}$ & $\begin{array}{l}-0.166 * * * \\
(0.056)\end{array}$ & $\begin{array}{l}-0.039 * * \\
(0.019)\end{array}$ & $\begin{array}{l}0.031 * * * \\
(0.008)\end{array}$ & $\begin{array}{l}-0.011 \\
(0.009)\end{array}$ \\
\hline Workers with at least a bachelor's degree & $\begin{array}{l}0.009 \\
(0.023)\end{array}$ & $\begin{array}{l}0.117 \\
(0.091)\end{array}$ & $\begin{array}{l}0.006 \\
(0.014)\end{array}$ & $\begin{array}{l}0.046 \\
(0.039)\end{array}$ & $\begin{array}{l}-0.028 * * * \\
(0.010)\end{array}$ \\
\hline
\end{tabular}

* - significant at the $10 \%$ level, ** - significant at the 5\% level, *** - significant at the $1 \%$ level

Note: The standard errors in parentheses are robust to clustering at the firm level. The sample consists of observations from 40,846 workers. The controls correspond to those in column 6 of table 2 with worker characteristics, indicators for broad occupations, and firm fixed effects. 
Appendix Table 1: Coefficient estimates for controls in specifications in table 2

\begin{tabular}{|c|c|c|c|c|c|}
\hline Variable & $\begin{array}{c}\text { Probability } \\
\text { of promotion } \\
\text { (1) }\end{array}$ & $\begin{array}{c}\text { Number of } \\
\text { promotions } \\
\text { (2) }\end{array}$ & (3) & g-wage grc & (5) \\
\hline 1 if female & $\begin{array}{l}-0.008 \\
(0.013)\end{array}$ & $\begin{array}{l}-0.089 * \\
(0.049)\end{array}$ & & & \\
\hline 1 if female and promoted & & & $\begin{array}{l}-0.029^{*} \\
(0.015)\end{array}$ & $\begin{array}{l}-0.027^{*} \\
(0.015)\end{array}$ & $\begin{array}{l}-0.029^{*} \\
(0.015)\end{array}$ \\
\hline 1 if female and not promoted & & & $\begin{array}{l}-0.016 * * \\
(0.007)\end{array}$ & $\begin{array}{l}-0.016 * * \\
(0.007)\end{array}$ & $\begin{array}{l}-0.016^{* *} \\
(0.007)\end{array}$ \\
\hline 1 if promoted & & & $\begin{array}{l}0.028^{* * * *} \\
(0.007)\end{array}$ & $\begin{array}{l}0.027 * * * \\
(0.007)\end{array}$ & $\begin{array}{l}0.027 * * * \\
(0.007)\end{array}$ \\
\hline 1 if visible minority, Canadian-born & $\begin{array}{l}-0.071 * \\
(0.041)\end{array}$ & $\begin{array}{l}-0.403 * * * \\
(0.109)\end{array}$ & $\begin{array}{l}-0.031 * * \\
(0.015)\end{array}$ & $\begin{array}{l}-0.028 * * \\
(0.013)\end{array}$ & $\begin{array}{l}-0.031^{* *} \\
(0.015)\end{array}$ \\
\hline 1 if white immigrant & $\begin{array}{l}0.005 \\
(0.021)\end{array}$ & $\begin{array}{l}-0.126^{*} \\
(0.074)\end{array}$ & $\begin{array}{l}-0.001 \\
(0.008)\end{array}$ & $\begin{array}{l}-0.004 \\
(0.008)\end{array}$ & $\begin{array}{l}-0.001 \\
(0.008)\end{array}$ \\
\hline 1 if visible minority immigrant & $\begin{array}{l}-0.035 \\
(0.024)\end{array}$ & $\begin{array}{l}-0.291 * * * \\
(0.085)\end{array}$ & $\begin{array}{l}-0.012 \\
(0.010)\end{array}$ & $\begin{array}{l}-0.011 \\
(0.010)\end{array}$ & $\begin{array}{l}-0.012 \\
(0.010)\end{array}$ \\
\hline 1 if home language is French & $\begin{array}{l}-0.034 \\
(0.023)\end{array}$ & $\begin{array}{l}0.118 \\
(0.097)\end{array}$ & $\begin{array}{l}-0.010 \\
(0.012)\end{array}$ & $\begin{array}{l}-0.004 \\
(0.010)\end{array}$ & $\begin{array}{l}-0.008 \\
(0.012)\end{array}$ \\
\hline 1 if home language is not French or English & $\begin{array}{l}-0.041^{*} \\
(0.024)\end{array}$ & $\begin{array}{l}-0.113 \\
(0.096)\end{array}$ & $\begin{array}{l}0.002 \\
(0.009)\end{array}$ & $\begin{array}{l}0.001 \\
(0.009)\end{array}$ & $\begin{array}{l}0.002 \\
(0.009)\end{array}$ \\
\hline 1 if highest degree is $\mathrm{MA} / \mathrm{PhD} / \mathrm{MD}$ & $\begin{array}{l}0.024 \\
(0.029)\end{array}$ & $\begin{array}{l}-0.073 \\
(0.127)\end{array}$ & $\begin{array}{l}0.005 \\
(0.012)\end{array}$ & $\begin{array}{l}-0.001 \\
(0.012)\end{array}$ & $\begin{array}{l}0.002 \\
(0.012)\end{array}$ \\
\hline 1 if highest degree is other graduate degree & $\begin{array}{l}-0.016 \\
(0.035)\end{array}$ & $\begin{array}{l}-0.188 \\
(0.152)\end{array}$ & $\begin{array}{l}-0.005 \\
(0.014)\end{array}$ & $\begin{array}{l}-0.012 \\
(0.014)\end{array}$ & $\begin{array}{l}-0.007 \\
(0.015)\end{array}$ \\
\hline 1 if highest degree is bachelor's degree & $\begin{array}{l}0.008 \\
(0.024)\end{array}$ & $\begin{array}{l}-0.109 \\
(0.101)\end{array}$ & $\begin{array}{l}0.004 \\
(0.010)\end{array}$ & $\begin{array}{l}0.001 \\
(0.010)\end{array}$ & $\begin{array}{l}0.002 \\
(0.010)\end{array}$ \\
\hline 1 if highest degree is some university & $\begin{array}{l}0.025 \\
(0.024)\end{array}$ & $\begin{array}{l}0.311^{* * *} \\
(0.112)\end{array}$ & $\begin{array}{l}-0.004 \\
(0.010)\end{array}$ & $\begin{array}{l}-0.005 \\
(0.010)\end{array}$ & $\begin{array}{l}-0.005 \\
(0.010)\end{array}$ \\
\hline 1 if highest degree is college or certificate program & $\begin{array}{l}0.029 \\
(0.022)\end{array}$ & $\begin{array}{l}0.038 \\
(0.094)\end{array}$ & $\begin{array}{l}0.0004 \\
(0.009)\end{array}$ & $\begin{array}{l}-0.0004 \\
(0.009)\end{array}$ & $\begin{array}{l}-0.001 \\
(0.009)\end{array}$ \\
\hline 1 if highest degree is some college & $\begin{array}{l}0.018 \\
(0.020)\end{array}$ & $\begin{array}{l}-0.004 \\
(0.082)\end{array}$ & $\begin{array}{l}0.003 \\
(0.008)\end{array}$ & $\begin{array}{l}0.003 \\
(0.009)\end{array}$ & $\begin{array}{l}0.002 \\
(0.008)\end{array}$ \\
\hline 1 if highest degree is high school graduate & $\begin{array}{l}0.027 \\
(0.022)\end{array}$ & $\begin{array}{l}0.038 \\
(0.092)\end{array}$ & $\begin{array}{l}0.011 \\
(0.009)\end{array}$ & $\begin{array}{l}0.010 \\
(0.009)\end{array}$ & $\begin{array}{l}0.011 \\
(0.009)\end{array}$ \\
\hline 1 if married & $\begin{array}{l}-0.022 \\
(0.020)\end{array}$ & $\begin{array}{l}0.004 \\
(0.059)\end{array}$ & $\begin{array}{l}0.014 * \\
(0.007)\end{array}$ & $\begin{array}{l}0.014 * * \\
(0.007)\end{array}$ & $\begin{array}{l}0.014 * * \\
(0.007)\end{array}$ \\
\hline 1 if common law status & $\begin{array}{l}-0.004 \\
(0.021)\end{array}$ & $\begin{array}{l}-0.008 \\
(0.064)\end{array}$ & $\begin{array}{l}0.009 \\
(0.012)\end{array}$ & $\begin{array}{l}0.008 \\
(0.012)\end{array}$ & $\begin{array}{l}0.009 \\
(0.012)\end{array}$ \\
\hline 1 if separated & $\begin{array}{l}-0.053 \\
(0.036)\end{array}$ & $\begin{array}{l}-0.119 \\
(0.117)\end{array}$ & $\begin{array}{l}0.024 \\
(0.021)\end{array}$ & $\begin{array}{l}0.022 \\
(0.021)\end{array}$ & $\begin{array}{l}0.025 \\
(0.021)\end{array}$ \\
\hline 1 if divorced & $\begin{array}{l}-0.017 \\
(0.026)\end{array}$ & $\begin{array}{l}-0.042 \\
(0.096)\end{array}$ & $\begin{array}{l}0.020^{*} \\
(0.010)\end{array}$ & $\begin{array}{l}0.020 * * \\
(0.009)\end{array}$ & $\begin{array}{l}0.020 * * \\
(0.010)\end{array}$ \\
\hline 1 if widowed & $\begin{array}{l}-0.084^{* *} \\
(0.037)\end{array}$ & $\begin{array}{l}-0.079 \\
(0.153)\end{array}$ & $\begin{array}{l}-0.016 \\
(0.020)\end{array}$ & $\begin{array}{l}-0.020 \\
(0.021)\end{array}$ & $\begin{array}{l}-0.016 \\
(0.020)\end{array}$ \\
\hline 1 if has one child & $\begin{array}{l}-0.009 \\
(0.014)\end{array}$ & $\begin{array}{l}0.005 \\
(0.055)\end{array}$ & $\begin{array}{l}0.002 \\
(0.006)\end{array}$ & $\begin{array}{l}0.001 \\
(0.006)\end{array}$ & $\begin{array}{l}0.002 \\
(0.006)\end{array}$ \\
\hline 1 if has two children & $\begin{array}{l}-0.002 \\
(0.014)\end{array}$ & $\begin{array}{l}0.030 \\
(0.050)\end{array}$ & $\begin{array}{l}-0.017 * * \\
(0.008)\end{array}$ & $\begin{array}{l}-0.014 * \\
(0.007)\end{array}$ & $\begin{array}{l}-0.017 * * \\
(0.008)\end{array}$ \\
\hline 1 if has three children & $\begin{array}{l}-0.025 \\
(0.019)\end{array}$ & $\begin{array}{l}-0.053 \\
(0.075)\end{array}$ & $\begin{array}{l}-0.004 \\
(0.009)\end{array}$ & $\begin{array}{l}-0.004 \\
(0.009)\end{array}$ & $\begin{array}{l}-0.003 \\
(0.009)\end{array}$ \\
\hline 1 if has four or more children & $\begin{array}{l}0.040 \\
(0.042)\end{array}$ & $\begin{array}{l}0.149 \\
(0.162)\end{array}$ & $\begin{array}{l}0.002 \\
(0.013)\end{array}$ & $\begin{array}{l}0.00002 \\
(0.012)\end{array}$ & $\begin{array}{l}0.001 \\
(0.013)\end{array}$ \\
\hline 1 if between age 25 and 29 & $\begin{array}{l}-0.038 \\
(0.035)\end{array}$ & $\begin{array}{l}-0.056 \\
(0.114)\end{array}$ & $\begin{array}{l}-0.008 \\
(0.015)\end{array}$ & $\begin{array}{l}-0.022 \\
(0.015)\end{array}$ & $\begin{array}{l}-0.007 \\
(0.015)\end{array}$ \\
\hline 1 if between age 30 and 34 & $\begin{array}{l}-0.106^{* * * *} \\
(0.036)\end{array}$ & $\begin{array}{l}-0.152 \\
(0.130)\end{array}$ & $\begin{array}{l}-0.020 \\
(0.016)\end{array}$ & $\begin{array}{l}-0.034 * * \\
(0.016)\end{array}$ & $\begin{array}{l}-0.019 \\
(0.016)\end{array}$ \\
\hline 1 if between age 35 and 39 & $\begin{array}{l}-0.104 * * * \\
(0.038)\end{array}$ & $\begin{array}{l}-0.277^{* *} \\
(0.131)\end{array}$ & $\begin{array}{l}-0.045^{*} \\
(0.024)\end{array}$ & $\begin{array}{l}-0.058 * * \\
(0.024)\end{array}$ & $\begin{array}{l}-0.044^{*} \\
(0.024)\end{array}$ \\
\hline
\end{tabular}




\begin{tabular}{|c|c|c|c|c|c|}
\hline \multicolumn{6}{|l|}{ Appendix Table 1 continued } \\
\hline \multirow[t]{2}{*}{1 if between age 40 and 44} & $-0.115 * * *$ & $-0.397 * * *$ & $-0.046^{* *}$ & $-0.056 * * *$ & $-0.045 * *$ \\
\hline & $(0.039)$ & $(0.131)$ & $(0.019)$ & $(0.018)$ & $(0.018)$ \\
\hline \multirow[t]{2}{*}{1 if between age 45 and 49} & $-0.140 * * *$ & $-0.374 * * *$ & $-0.043 *$ & $-0.054 * *$ & $-0.042 *$ \\
\hline & $(0.039)$ & $(0.136)$ & $(0.022)$ & $(0.022)$ & $(0.022)$ \\
\hline \multirow[t]{2}{*}{1 if between age 50 and 54} & $-0.176^{* * *}$ & $-0.481 * * *$ & $-0.046 * *$ & $-0.058 * *$ & $-0.045^{* *}$ \\
\hline & $(0.039)$ & $(0.140)$ & $(0.023)$ & $(0.023)$ & $(0.023)$ \\
\hline \multirow[t]{2}{*}{1 if between age 55 and 59} & $-0.164 * * *$ & $-0.460 * * *$ & $-0.047 * *$ & $-0.059 * * *$ & $-0.046^{* *}$ \\
\hline & $(0.042)$ & $(0.151)$ & $(0.023)$ & $(0.022)$ & $(0.022)$ \\
\hline \multirow[t]{2}{*}{1 if between age 60 and 65} & $-0.202 * * *$ & $-0.775 * * *$ & -0.033 & $-0.052 * *$ & -0.031 \\
\hline & $(0.045)$ & $(0.161)$ & $(0.022)$ & $(0.022)$ & $(0.022)$ \\
\hline \multirow[t]{2}{*}{ Year of work experience } & -0.002 & $0.032 * * *$ & 0.003 & 0.002 & 0.003 \\
\hline & $(0.002)$ & $(0.008)$ & $(0.002)$ & $(0.002)$ & $(0.002)$ \\
\hline \multirow[t]{2}{*}{ Years of work experience squared } & 0.002 & $-0.037 *$ & $-0.007 *$ & -0.005 & $-0.007 *$ \\
\hline & $(0.005)$ & $(0.019)$ & $(0.004)$ & $(0.004)$ & $(0.004)$ \\
\hline \multirow[t]{2}{*}{1 if job is in a union or covered by a CBA } & $-0.098 * * *$ & $-0.451 * * *$ & -0.003 & -0.001 & -0.003 \\
\hline & $(0.014)$ & $(0.063)$ & $(0.007)$ & $(0.006)$ & $(0.007)$ \\
\hline \multirow[t]{2}{*}{1 if year 2000} & $-0.026^{* *}$ & $-0.165 * * *$ & -0.003 & 0.001 & -0.004 \\
\hline & $(0.011)$ & $(0.046)$ & $(0.006)$ & $(0.006)$ & $(0.006)$ \\
\hline \multirow[t]{2}{*}{1 if year 2002} & $0.094 * * *$ & $0.081 *$ & -0.006 & -0.007 & -0.006 \\
\hline & $(0.013)$ & $(0.044)$ & $(0.005)$ & $(0.005)$ & $(0.005)$ \\
\hline \multirow[t]{2}{*}{1 if a managerial occupation } & $0.068 * *$ & $0.940 * * *$ & $0.034 * * *$ & $0.029 * *$ & $0.032 * * *$ \\
\hline & $(0.028)$ & $(0.097)$ & $(0.011)$ & $(0.012)$ & $(0.011)$ \\
\hline \multirow[t]{2}{*}{1 if a professional occupation } & 0.038 & $0.384 * * *$ & $0.033 * * *$ & $0.027 * *$ & $0.030 * * *$ \\
\hline & $(0.024)$ & $(0.081)$ & $(0.010)$ & $(0.011)$ & $(0.011)$ \\
\hline \multirow[t]{2}{*}{1 if a technical occupation or trade } & 0.028 & $0.348 * * *$ & 0.011 & 0.008 & 0.010 \\
\hline & $(0.022)$ & $(0.067)$ & $(0.011)$ & $(0.012)$ & $(0.011)$ \\
\hline \multirow[t]{2}{*}{1 if a marketing or sales occupation } & -0.039 & -0.075 & 0.027 & 0.027 & 0.026 \\
\hline & $(0.040)$ & $(0.134)$ & $(0.025)$ & $(0.023)$ & $(0.025)$ \\
\hline \multirow[t]{2}{*}{1 if a clerical or administrative occupation } & 0.006 & 0.082 & $0.018^{*}$ & 0.013 & $0.017 *$ \\
\hline & $(0.024)$ & $(0.076)$ & $(0.009)$ & $(0.010)$ & $(0.010)$ \\
\hline \multirow[t]{2}{*}{ Usual hours per week worked } & & & & -0.001 & \\
\hline & & & & $(0.001)$ & \\
\hline \multirow[t]{2}{*}{ Weeks worked per year } & & & & $-0.001 *$ & \\
\hline & & & & $(0.001)$ & \\
\hline \multirow[t]{2}{*}{ Number of employees supervised } & & & & -0.00001 & \\
\hline & & & & $(0.00003)$ & \\
\hline Number of unpaid overtime hours per week & & & & 0.001 & \\
\hline & & & & $(0.001)$ & \\
\hline Change in usual hours per week worked & & & & $-0.009 * * *$ & \\
\hline & & & & $(0.001)$ & \\
\hline Change in weeks worked per year & & & & $-0.004 * * *$ & \\
\hline & & & & $(0.001)$ & \\
\hline Change in number of employees supervised & & & & $0.00004 *$ & \\
\hline & & & & $(0.00002)$ & \\
\hline Change in number of unpaid overtime hours per week & & & & $0.002 * * *$ & \\
\hline & & & & $(0.001)$ & \\
\hline 1 if received on-the-job training (OJT) & & & & & $0.013 *$ \\
\hline & & & & & $(0.007)$ \\
\hline Number of days of OJT in the previous year & & & & & -0.0001 \\
\hline & & & & & $(0.0002)$ \\
\hline 1 if declined to participate in OJT through employer & & & & & $0.010 *$ \\
\hline & & & & & $(0.006)$ \\
\hline 1 if participated in training not through employer & & & & & 0.007 \\
\hline & & & & & $(0.008)$ \\
\hline
\end{tabular}

Note: Columns 1, 2 and 3 correspond to column 6 in table 2 for panels A, B, and C, respectively, while columns 4 and 5 correspond to columns 7 and 8 of panel $\mathrm{C}$ in table 2 . The standard errors in parentheses are robust to clustering at the firm level. The sample consists of observations from 40,846 workers. 